\title{
NITROGEN STORAGE AND CYCLING IN OLD- AND SECOND-GROWTH NORTHERN HARDWOOD FORESTS
}

\author{
Melany C. Fisk, ${ }^{1,2}$ Donald R. ZaK, ${ }^{1}$ And Thomas R. Crow ${ }^{3}$ \\ ${ }^{1}$ School of Natural Resources and Environment, University of Michigan, Ann Arbor, Michigan 48109-1115 USA
}

\begin{abstract}
Ecosystem retention of $\mathrm{N}$ is mediated by interactions among plant, soil, and microbial processes. These are likely to change with forest ecosystem development as living plant biomass accumulation slows and detrital biomass increases. We investigated linkages among $\mathrm{N}$ storage, $\mathrm{N}$ cycling processes, and $\mathrm{N}$ leaching losses in a study of replicate midsuccessional (80-yr-old) and late-successional (uneven-aged old-growth) northern hardwood forests in the western upper peninsula of Michigan, USA. Our study tested hypotheses that detrital biomass and microbial immobilization of $\mathrm{N}$ function as larger $\mathrm{N}$ sinks and correspond to greater $\mathrm{N}$ retention in old-growth compared to maturing second-growth forests. Aboveground living and detrital biomass pools were greater in old-growth compared to second-growth forest, a difference due largely to coarse woody debris (CWD). The total amount of $\mathrm{N}$ in detrital pools was significantly greater in old-growth than second-growth forests. We also found more rapid rates of microbial $\mathrm{N}$ immobilization in old-growth forests than in second-growth forests. In situ net $\mathrm{N}$ mineralization ranged widely among individual stands and did not differ between old- and second-growth forests. Nitrogen (organic + inorganic) leaching did not differ significantly between old-growth and second-growth forests, and was substantially lower than wet deposition inputs. Nitrate leaching losses were significantly related to soil $\mathrm{NO}_{3}{ }^{-}$pools, litterfall $\mathrm{N}$ flux, and fine root biomass across both old- and second-growth forest stands. We conclude that CWD and microbial N uptake and turnover are greater $\mathrm{N}$ sinks in old-growth than in second-growth forests. This apparent $\mathrm{N}$ sink was not the primary factor influencing $\mathrm{N}$ leaching loss, however. Patterns of $\mathrm{N}$ dynamics among individual forest ecosystems indicate that $\mathrm{N}$ losses correspond to net rates of $\mathrm{N}$ mineralization and to litterfall $\mathrm{N}$ flux (indicators of plant $\mathrm{N}$ cycling), which are independent of forest age, biomass pools, and gross $\mathrm{N}$ transformations at the successional stages that we compared.
\end{abstract}

Key words: coarse woody debris; dissolved organic nitrogen; microbial nitrogen uptake; nitrogen cycling; nitrogen immobilization; nitrogen leaching; nitrogen storage; old-growth forests.

\section{INTRODUCTION}

Nitrogen $(\mathrm{N})$ retention varies widely among forest ecosystems (Hedin et al. 1995), and explanation of the patterns and mechanisms of $\mathrm{N}$ retention are central to our general understanding of $\mathrm{N}$ limitation and of ecosystem function in $\mathrm{N}$ cycles. Losses of $\mathrm{N}$ that limit its ability to accumulate in an ecosystem depend upon rates of $\mathrm{N}$ transformations and upon quantities of mobile $\mathrm{NO}_{3}{ }^{-}$that are available in soil solution (Vitousek et al. 1998). Ecosystem theory predicts that these losses change with successional status, or time since largescale disturbance, of forest ecosystems. For example, Vitousek and Reiners (1975) proposed that successional patterns of biomass accumulation regulate the

Manuscript received 28 March 2000; revised 28 December 2000; accepted 3 January 2001; final version received 6 January 2001.

${ }^{2}$ Present address: Department of Biology, Appalachian State University, 572 Rivers St., Boone, North Carolina 28608-2027 USA.

${ }^{3}$ USDA Forest Service, North Central Research Station, Forestry Sciences Laboratory, Grand Rapids, Minnesota 55744 USA loss of limiting nutrients, such as $\mathrm{N}$, from terrestrial ecosystems (the nutrient retention hypothesis).

Experimental tests of the nutrient retention hypothesis have had different outcomes depending on forest age, suggesting that factors other than plant $\mathrm{N}$ demand and sequestration limit $\mathrm{N}$ losses in older forests. For example, low $\mathrm{N}$ losses have been observed early in succession (Vitousek 1977, Martin 1979, Pardo et al. 1995) when forest biomass accumulates rapidly. Available $\mathrm{N}$ pools were probably kept at a minimum by high plant demand in these young forests. However, $\mathrm{N}$ losses from old-growth forests (Martin 1979, Sollins et al. 1980), or those in which overstory biomass accumulation has ceased (C. T. Driscoll, unpublished data; Likens et al. 1994), have been lower than predicted by the nutrient retention hypothesis. Nitrogen retention apparently continues in some forest ecosystems after plant biomass accumulation slows.

As forests mature, $\mathrm{N}$ retention may be influenced to a greater extent by heterotrophic processes that regulate internal $\mathrm{N}$ supply and its storage in detritus. Several factors suggest changes in heterotroph processing of $\mathrm{N}$ as forests age. Organic matter substrates are likely to change in both quantity and quality with forest age. 
For example, total quantities of detrital biomass increase as forests age (Sollins et al. 1980, Harmon et al. 1986, McCarthy and Bailey 1994, Goodburn and Lorimer 1998, Hale et al. 1999). The chemical nature and decomposition of litter also differ in older forests (Gorham et al. 1979, Vitousek et al. 1988, Gower et al. 1996). It is not certain how microbial $\mathrm{N}$ cycling processes respond to these changes, but there is evidence of greater microbial $\mathrm{N}$ immobilization in oldgrowth compared to second-growth forests (Davidson et al. 1992). This immobilization can minimize $\mathrm{NO}_{3}{ }^{-}$ production (Davidson et al. 1992) and thus might limit leaching losses. Furthermore, several studies indicate that microbial uptake and turnover can sequester $\mathrm{N}$ in forest soils (Vitousek and Matson 1985, He et al. 1988, Schimel and Firestone 1989a, Couteaux and Sallih 1994, Hart and Stark 1997, Fenn et al. 1998, Zogg et al. 2000). It is therefore plausible that a greater heterotrophic sink for $\mathrm{N}$ exists in old-growth forests.

To better understand the mechanisms by which microbial $\mathrm{N}$ cycling influences $\mathrm{N}$ losses, we examined relationships among $\mathrm{N}$ storage, microbial and plant $\mathrm{N}$ cycling processes, and leaching loss in second-growth (80-yr-old) and uneven-aged old-growth northern hardwood forests located in Michigan's upper peninsula. We expected the available $\mathrm{NO}_{3}^{-}$pool to be the greatest potential source for $\mathrm{N}$ loss in these forests. Dissolved organic $\mathrm{N}$ was also considered as an avenue for $\mathrm{N}$ loss, although this is thought to be most important in forests that receive little to no $\mathrm{N}$ deposition (Hedin et al. 1995). In order to focus on the comparisons of detrital pools and microbial processes, we chose second-growth forests that were relatively mature so that $\mathrm{N}$ sequestration in aggrading overstory biomass would not be high. We expected detrital pools to influence microbial $\mathrm{N}$ cycling to a greater extent in old- than second-growth forests, decreasing available $\mathrm{N}$ pools and, ultimately, $\mathrm{N}$ losses. We tested these ideas as a series of related hypotheses, that in old-growth compared to second-growth forests: (1) detrital biomass is greater, (2) gross $\mathrm{N}$ transformations are greater, with proportionately higher microbial $\mathrm{N}$ immobilization, (3) net $\mathrm{N}$ mineralization and nitrification are limited by microbial immobilization to a greater extent, and (4) $\mathrm{N}$ leaching is lower because of lower available $\mathrm{NO}_{3}{ }^{-}$pools.

\section{Methods \\ Study sites}

We studied sugar maple (Acer saccharum Marsh.)dominated northern hardwood forests in the southwestern upper peninsula of Michigan (Fig. 1). Other common tree species include yellow birch (Betula alleghaniensis Britton), basswood (Tilia americana L.), eastern hemlock (Tsuga canadensis (L.) Carr.), and ironwood (Ostrya virginiana (Mill.) K. Koch). Study sites were located in Albert's (1994) Sub-Subsection IX.3.2 (Winegar Moraine) on landforms that are irreg-

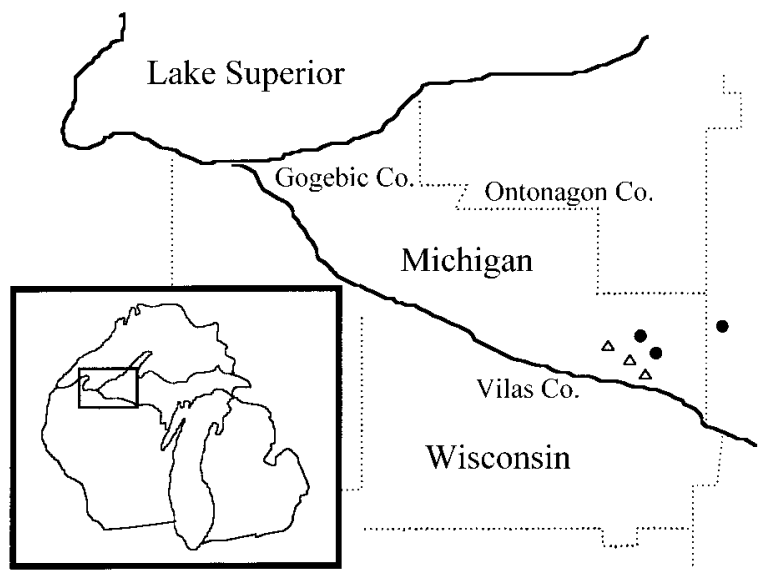

FIG. 1. Location of study sites in western Upper Michigan. Triangles represent old-growth forest ecosystems, and circles represent second-growth forest ecosystems.

ular lobes of a terminal moraine with varying slope. Soils were fine sandy loam haplorthods or fragiorthods from the Gogebic Series. To minimize variation in the physical environment, sampling was limited to ecosystems mapped as Ecological Landtype Phase (ELTP) 38B or 38C within the Sub-Subsection (Albert 1994). Both ELTP's are Acer-Tsuga-Dryopteris associations on sandy loam soil, but they differ in slope (ELTP 38B 1-6\%; ELTP 38C 6-18\%). Within this framework, we selected forest stands that were similar in terms of plant species composition, soil characteristics, landform, and climate, but differed in successional stage. These criteria, plus management history and accessibility for research, limited the number of forest stands available and did not enable us to choose study sites from a larger pool of available sites.

We studied three uneven-aged, old-growth forest stands (O-1, O-2, and O-3) in the Watersmeet District on the Ottawa National Forest (Fig. 1). USDA Forest Service records indicated that they had never been harvested or otherwise managed. They initially were part of a large privately owned reserve that became the Sylvania Wilderness Area. Old-growth stands had a wide variety of tree ages, but each was dominated by large-diameter individuals ranging from 200 to $300 \mathrm{yr}$ old (Crow et al. 2001). The three additional stands (S1, S-2, and S-3) were even-aged, second-growth forests located in the Watersmeet and Iron River Districts on the Ottawa National Forest, near and around the perimeter of the Sylvania Wilderness Area (Fig. 1). These stands originated after commercial clearcutting between 1918 and 1920, and they have not been managed since their initial harvest. They were dominated by trees 60-80 yr old with an occasional residual tree 120200 yr old (Crow et al. 2001).

We randomly located eight points along a 100-m transect in each stand. From each point, we designated a sampling plot at a random distance $(0$ to $100 \mathrm{~m})$ 
perpendicular to the transect. These eight sampling plots, or random subsets of them, were used for all of our measurements with the exception of basal area and overstory biomass. Basal area and overstory biomass were quantified in separate, randomly located $833-\mathrm{m}^{2}$ plots in each stand. Replication of plots within a stand enabled us to make comparisons among individual stands, whereas replication of stands in an ecosystem type (i.e., second vs. old growth) enabled us to compare forests of different age. All measurements were made in 1995 unless otherwise noted.

Organic matter, total $\mathrm{N}, \mathrm{pH}$, and soil texture were measured on subsamples of soil cores (six per stand) collected from the surface of the Oe horizon to a depth of $15 \mathrm{~cm}$. Oe plus Oa horizons varied from 0 to $4 \mathrm{~cm}$ depth, and accounted for $\leq 15 \%$ of the mass of the entire core. Organic matter was measured by loss on ignition at $450^{\circ} \mathrm{C}$. Total $\mathrm{N}$ was measured using Kjeldahl digestion in $\mathrm{H}_{2} \mathrm{SO}_{4}$ with a cupric sulfate catalyst, followed by analysis for $\mathrm{NH}_{4}{ }^{+}$using an Alpkem rapid flow analyzer (RFA 300, Alpkem, Clackamas, Oregon, USA). Soil $\mathrm{pH}$ was measured with a glass electrode in a 1:1 soil:water paste. Percentages sand, silt, and clay were quantified by the hydrometer method (Sheldrick and Wang 1993).

\section{Biomass and nitrogen pools}

Overstory biomass was estimated in three randomly located $833-\mathrm{m}^{2}$ plots in each second- and old-growth stand. Tree height and diameter at breast height (dbh) were measured for all stems $>1.5 \mathrm{~cm}$ dbh. Speciesspecific allometric equations for trees in the Lakes States region were used to estimate total aboveground biomass (Host et al. 1989). Seven percent of stems (49\% of basal area) exceeded upper diameter limits of the allometric equations $(50 \mathrm{~cm})$ in old-growth plots, leading to some uncertainty in our biomass estimates for those trees. Total aboveground biomass of each tree was partitioned into bole, bark, branch, twig, and leaf using the equations of Crow (1978). We used N concentations reported for each component by Pastor and Bockheim (1984) and estimated tree $\mathrm{N}$ content as the product of mass and $\mathrm{N}$ concentration.

We used a line intercept method to quantify coarse ( $>5 \mathrm{~cm}$ diameter) and fine $(2-5 \mathrm{~cm}$ diameter) woody debris (Van Wagner 1968). We measured the diameter of all woody debris $>2 \mathrm{~cm}$ in diameter that intersected three 120-m transects in each second- and old-growth stand. The 120-m transects were broken into equilateral triangles to avoid bias associated with nonrandom orientation of woody debris (Van Wagner 1968). Starting points and angle of orientation for the triangles were chosen randomly within each stand. All debris sampled was assigned a decay class from I (least decomposed) to $\mathrm{V}$ (most highly decomposed), using the classifications of Sollins (1982) and Tyrrell and Crow (1994).

Wood density and $\mathrm{N}$ concentrations were quantified for one cross-section taken from each piece of woody debris on one side of a triangle in each stand. Average densities, determined for cross sections of each decay class, were used to convert coarse woody debris (CWD) and fine woody debris (FWD) volumes into masses. Entire cross-section samples were ground $(425-\mu \mathrm{m}$ mesh) and subsamples were digested and analyzed for $\mathrm{N}$ concentration. Average $\mathrm{N}$ concentrations for each decay class were used to estimate woody debris $\mathrm{N}$ from mass.

Forest floor mass was estimated from $\mathrm{Oe}$ and $\mathrm{Oa}$ horizon material collected in $0.09 \mathrm{~m}^{2}$ frames in six of our eight sampling plots in each stand. The Oi horizon, which we defined as the current year's fresh litter, varies seasonally and so was not included these forest floor samples. Leaf litterfall was collected in the same six plots in $0.20-\mathrm{m}^{2}$ baskets per stand in September and October following leaf-fall. Forest floor and litter samples were ground in a mill $(425-\mu \mathrm{m}$ mesh) and total $\mathrm{N}$ content was determined using the Kjeldahl procedure.

Fine root biomass $(<2 \mathrm{~mm}$ diameter $)$ was measured in $5 \mathrm{~cm}$ diameter cores collected to a depth of $15 \mathrm{~cm}$ from the Oe horizon surface. Six cores per stand were collected in the last week of June 1995 and in the first week of August 1996; samples were refrigerated for up to $3 \mathrm{wk}$ until roots could be separated from soil by hand.

\section{Gross nitrogen transformations}

We used a short-term ${ }^{15} \mathrm{~N}$ pool dilution technique to quantify rates of gross $\mathrm{N}$ transformations in July 1995 . At three sampling locations in each stand, we collected six $5 \mathrm{~cm}$ diameter cores to a $15 \mathrm{~cm}$ depth from the surface of the Oe horizon. Cores were removed from the soil and ${ }^{15} \mathrm{~N}$ was injected in solution using a spinal tap needle modified to have six side injection ports at its end; three cores received ${ }^{15} \mathrm{NH}_{4} \mathrm{Cl}$ and three received $\mathrm{K}^{15} \mathrm{NO}_{3}$. Isotope was added in six 2-mL injections throughout the length of each core; both solutions were $0.1 \mu \mathrm{g} \mathrm{N} / \mathrm{mL}\left(99 \%{ }^{15} \mathrm{~N}\right.$ enrichment). These injections caused an increase from $37 \%$ to $42 \%$ in gravimetric soil water content.

From each set of six cores, one ${ }^{15} \mathrm{NH}_{4}{ }^{+}$-labeled core and one ${ }^{15} \mathrm{NO}_{3}{ }^{-}$-labeled core were homogenized $30 \mathrm{~min}$ following injection, and $\sim 25$-g fresh-mass subsamples were immediately extracted by shaking in $100 \mathrm{~mL} \mathrm{2-}$ $\mathrm{mol} / \mathrm{L} \mathrm{KCl}$. From these extractions, we determined initial soil inorganic $\mathrm{N}$ concentrations and percentage ${ }^{15} \mathrm{~N}$ enrichment. A second subsample from each core was used to measure gravimetric soil water content $(24 \mathrm{~h}$ at $100^{\circ} \mathrm{C}$ ). Additional subsamples were used to quantify microbial $\mathrm{N}$ using the chloroform fumigation-extraction procedure $\left(K_{n}=0.54\right.$; Brookes et al. [1985], Davidson et al. [1989]).

Remaining cores were incubated in the field for 48 h. Following incubation, two ${ }^{15} \mathrm{NH}_{4}{ }^{+}$-labeled cores from each sample location were removed from the soil and composited in the field. A homogenized subsample from each set of composited cores was extracted in 2- 
$\mathrm{mol} / \mathrm{L} \mathrm{KCl}$ for final soil inorganic $\mathrm{N}$ concentration and ${ }^{15} \mathrm{~N}$ enrichment analyses. Gravimetric water content was measured on additional subsamples.

Soil extracts were allowed to settle for $24 \mathrm{~h}$ after shaking, filtered through $0.45-\mu \mathrm{m}$ Nucleopore filter membranes, and stored at $4{ }^{\circ} \mathrm{C}$ prior to analysis. Ammonium and $\mathrm{NO}_{3}{ }^{-}$concentrations in soil extracts were analyzed within $1 \mathrm{wk}$ using the Alpkem RFA. Net $\mathrm{N}$ mineralization was calculated as the difference in $\mathrm{NH}_{4}{ }^{+}$ and $\mathrm{NO}_{3}^{-}$concentrations between final and initial extracts. A diffusion procedure similar to that of Brooks et al. (1989) was used to collect ${ }^{15} \mathrm{NH}_{4}{ }^{+}$and ${ }^{15} \mathrm{NO}_{3}{ }^{-}$; ${ }^{15} \mathrm{~N}$ enrichment was determined using a Europa Scientific Integra $\mathrm{CN}$ mass spectrometer (Europa Scientific, Vandalia, Ohio, USA). Gross $\mathrm{N}$ mineralization, gross nitrification, and $\mathrm{N}$ consumption were calculated using the equations of Kirkham and Bartholomew (1954). Ammonium immobilization was estimated as $\mathrm{NH}_{4}{ }^{+}$consumption minus gross nitrification (Hart et al. 1994b). Nitrate immobilization was assumed to be equal to $\mathrm{NO}_{3}{ }^{-}$consumption $\mathrm{m}$. We also estimated total $\mathrm{N}$ immobilization $\left(\mathrm{NH}_{4}\right.$ plus $\left.\mathrm{NO}_{3}{ }^{-}\right)$as gross $\mathrm{N}$ mineralization minus net $\mathrm{N}$ mineralization, measured in the same cores. In either approach, immobilization may be overestimated if addition of $\mathrm{N}$ stimulates its uptake.

\section{In situ net nitrogen transformations}

Net $\mathrm{N}$ mineralization and nitrification were measured in situ using a buried bag method (Eno 1960). These measurements were initiated on 15 June 1995 and continued through 15 October 1995. At six sampling locations in each forest stand, four soil cores $(5-\mathrm{cm}$ diameter) were collected from the surface of the Oe horizon to a depth of $15 \mathrm{~cm}$. Two soil cores were mixed together and extracted in $2-\mathrm{mol} / \mathrm{L} \mathrm{KCl}$, and analyzed for $\mathrm{NO}_{3}{ }^{-}$and $\mathrm{NH}_{4}{ }^{+}$concentrations The remaining two cores were enclosed in plastic bags and returned to their original positions in the soil. Following $1 \mathrm{mo}$ of field incubation, these cores were collected from the field, mixed together, and analyzed for $\mathrm{NH}_{4}{ }^{+}$and $\mathrm{NO}_{3}{ }^{-}$. Net $\mathrm{N}$ mineralization was estimated as the difference between the incubated and initial inorganic $\mathrm{N}$ for each composited sample; net nitrification was estimated as the difference in $\mathrm{NO}_{3}{ }^{-}$.

\section{Nitrogen loss}

Nitrogen leaching is probably the major pathway for $\mathrm{N}$ loss in our study sites, given the relatively low denitrification in the well-drained soils of the sugar-maple-dominated northern hardwood forests in the Lake States region (Merrill and Zak 1992, Holmes and Zak 1999). We estimated the leaching loss of organic and inorganic $\mathrm{N}$ in second- and old-growth stands with porous-cup tension lysimeters placed at a depth of $1 \mathrm{~m}$. Lysimeters were installed in June 1995, left at a tension of $30 \mathrm{kPa}$, and evacuated monthly from July 1995 to October 1997. Although soil solution was collected monthly, analyses for inorganic and organic $\mathrm{N}$ were not initiated until April 1996, to allow regrowth of roots and minimize disturbance effects. Beginning April 1996, soil solution from each lysimeter was filtered $(0.45 \mu \mathrm{m})$ within $12 \mathrm{~h}$ of field collection and stored at $4^{\circ} \mathrm{C}$ prior to analyses for $\mathrm{NO}_{3}{ }^{-}$and $\mathrm{NH}_{4}{ }^{+}$. Nitrate always was the dominant form of inorganic $\mathrm{N}(>98 \%)$ in soil solution; therefore, soil solution $\mathrm{NH}_{4}{ }^{+}$concentrations and leaching are not presented. Total dissolved $\mathrm{N}$ was quantified using a persulfate oxidation procedure (D'Elia et al. 1977), followed by $\mathrm{NO}_{3}{ }^{-}$analysis on an Alpkem RFA 300. Dissolved organic N was estimated as the difference between total dissolved $\mathrm{N}$ and $\mathrm{NO}_{3}{ }^{-}$.

We used the BROOK water-balance model (Federer and Lash 1978, Vorosmarty et al. 1998) to estimate the volume of water leaching below the rooting zone of these second- and old-growth forests. Precipitation data for the model were obtained from the nearby $(45 \mathrm{~km})$ Trout Lake National Atmospheric Deposition Program (NADP) station (National Atmospheric Deposition Program (NRSP-3)/National Trends Network [1999]). Maximum and minimum daily temperatures were obtained from our study sites. We estimated monthly $\mathrm{N}$ leaching as the product of soil solution $\mathrm{N}$ concentration and the volume of water moving below the rooting zone.

We also used data from the Trout Lake National Atmospheric Deposition Program (NADP) station (National Atmospheric Deposition Program (NRSP-3)/National Trends Network [1999]) to estimate N deposition in second- and old-growth stands. Nitrogen contained in wet deposition was available for this site $\left(\mathrm{NO}_{3}{ }^{-} \mathrm{N}\right.$ plus $\left.\mathrm{NH}_{4}{ }^{+}-\mathrm{N}\right)$, but we were unable to obtain estimates of dry $\mathrm{N}$ deposition. Consequently, the exclusion of dry deposition provides a conservative estimate of atmospheric $\mathrm{N}$ input to our sites.

\section{Statistical analyses}

We used a mixed-model ANOVA to analyze differences in biomass pools, $\mathrm{N}$ transformations, and $\mathrm{N}$ leaching between second- and old-growth stands. The model had forest stands nested as random effects within forest age (fixed effects). In this model, we tested for significant forest age effects using the mean square of the stands $\times$ forest age interaction in the denominator of the $F$ ratio. Significance of stand effects was tested using the mean square error in the denominator of the $F$ ratio (Sokal and Rohlf 1981). This nested design allowed us to make comparisons among individual forest stands as well as between replicate old- and secondgrowth forest stands (Sokal and Rohlf 1981). For those measurements conducted over time, we used a repeated-measures ANOVA with time as the within-subjects factor. Relationships among variables were explored using correlation analysis. SAS (SAS Institute, Cary, North Carolina, USA) was used for all analyses, and significance for all analyses was accepted at $\alpha=0.05$. 
TABLE 1. Overstory and soil characteristics (15 cm depth from Oe surface) in old- and secondgrowth northern hardwood forest ecosystems in western Upper Michigan, USA.

\begin{tabular}{|c|c|c|c|c|c|c|c|c|}
\hline \multirow{2}{*}{$\begin{array}{l}\text { Ecosys- } \\
\text { tem }\end{array}$} & \multirow{2}{*}{$\begin{array}{c}\text { Basal } \\
\text { area } \\
\left(\mathrm{m}^{2} / \mathrm{ha}\right)\end{array}$} & \multirow{2}{*}{$\begin{array}{c}\text { Stem } \\
\text { density } \\
\text { (number/ha) }\end{array}$} & \multirow{2}{*}{$\begin{array}{c}\text { Soil } \\
\text { organic } \\
\text { matter } \\
(\mathrm{g} / \mathrm{kg})\end{array}$} & \multirow{2}{*}{$\begin{array}{l}\text { Soil N } \\
(\mathrm{g} / \mathrm{kg})\end{array}$} & \multirow[b]{2}{*}{ Soil pH } & \multicolumn{3}{|c|}{$\begin{array}{l}\text { Soil texture (percentage } \\
\text { compostion) }\end{array}$} \\
\hline & & & & & & Sand & Silt & Clay \\
\hline \multicolumn{9}{|c|}{ Old Growth } \\
\hline O-1 & $29(2.0)$ & $1110(204)$ & $59(5)$ & $1.8(0.1)$ & $4.5(0.1)$ & $57(2)$ & $36(2)$ & $6(1)$ \\
\hline $\mathrm{O}-2$ & $36(3.8)$ & 970 (130) & $50(7)$ & $1.7(0.2)$ & $4.9(0.2)$ & $69(2)$ & $28(2)$ & $3(1)$ \\
\hline $\mathrm{O}-3$ & $33(3.3)$ & $1300(205)$ & $52(5)$ & $1.6(0.1)$ & $4.8(0.2)$ & $64(4)$ & $32(3)$ & $4(1)$ \\
\hline Mean & $33(2.0)$ & $1130(96)$ & $54(3)$ & $1.6(0.1)$ & $4.7(0.1)$ & $63(3)$ & $32(2)$ & $4(1)$ \\
\hline \multicolumn{9}{|c|}{ Second Growth } \\
\hline S-1 & $28(1.8)$ & $750(160)$ & $34(3)$ & $1.3(0.1)$ & $4.6(0.2)$ & $81(1)$ & $15(1)$ & $4(1)$ \\
\hline S-2 & $30(1.2)$ & $1120(124)$ & $68(8)$ & $2.0(0.2)$ & $4.6(0.1)$ & $62(3)$ & $32(3)$ & $6(1)$ \\
\hline S-3 & $34(1.1)$ & $1040(97)$ & $64(6)$ & $1.8(0.1)$ & $5.2(0.2)$ & $68(2)$ & $27(2)$ & $5(1)$ \\
\hline Mean & $31(1.8)$ & 970 (112) & $55(10)$ & $1.7(0.2)$ & $4.8(0.2)$ & $70(6)$ & $25(5)$ & $5(1)$ \\
\hline
\end{tabular}

Notes: Standard errors of the mean are in parentheses. For each stand, $n=3$ for basal area and stem density, and $n=6$ for soil characteristics. For old- and second-growth forest means, $n=3$ stands.

\section{RESULTS}

\section{Stand characteristics}

Stand basal area and stem density varied little between the old-growth and second-growth forests (Table 1), whereas stem size-class distribution clearly differed between forests of different age. Most of basal area in second-growth stands occurred in intermediate size classes $(20-40 \mathrm{~cm} \mathrm{dbh})$, whereas basal area in old-
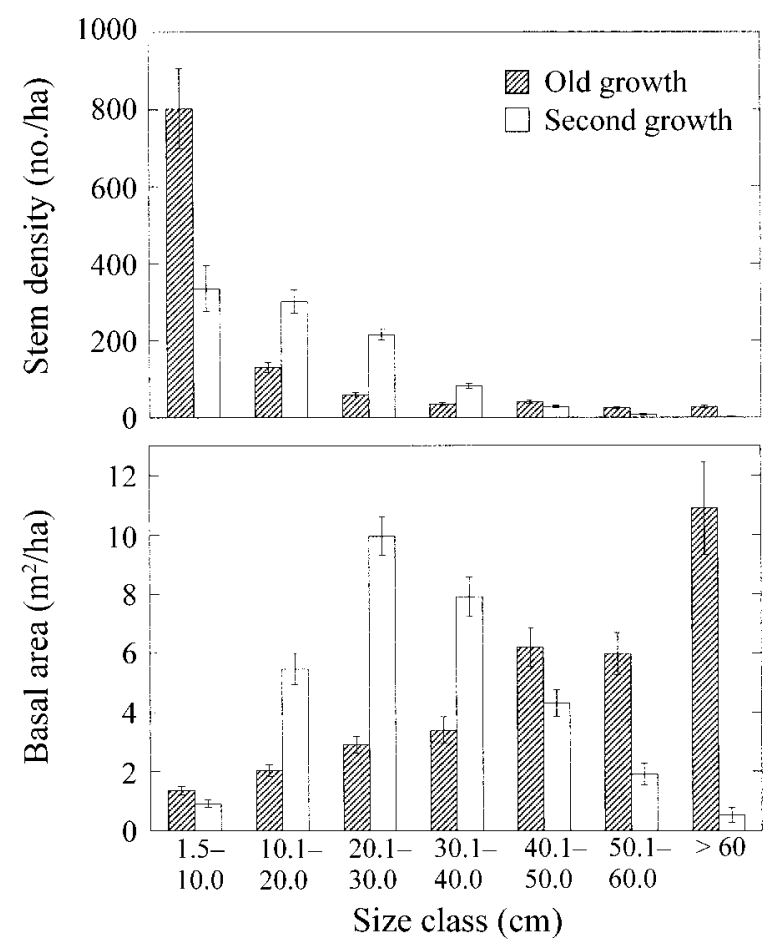

FIG. 2. Size class distributions (10-cm classes) of (top panel) stem numbers and (bottom panel) basal areas for all living woody stems $>1.5 \mathrm{~cm}$ diameter in old- and secondgrowth northern hardwood forests. Data are means \pm 1 standard error of the mean (SE). growth stands was dominated by large stems $(>50 \mathrm{~cm}$ dbh; Fig. 2). Soil organic matter, total N, pH, and soil texture varied little among forest stands (Table 1) and were similar in second- and old-growth ecosystems.

\section{Biomass and nitrogen pools}

Living plus detrital biomass was significantly greater in old-growth (350 $\pm 6 \mathrm{Mg} / \mathrm{ha})$ compared to secondgrowth forests $(290 \pm 11 \mathrm{Mg} / \mathrm{ha}$; Table 2$)$. Live overstory biomass of $262 \mathrm{Mg} / \mathrm{ha}$ in old-growth forest and $230 \mathrm{Mg} / \mathrm{ha}$ in second-growth forest did not differ significantly (Table 2), despite obvious differences in overstory structure (Fig. 2). Biomass in standing dead trees, forest floor, litterfall, and fine roots $(0-15 \mathrm{~cm}$ depth) also did not differ significantly between oldand second-growth forests (Table 2). Fine woody debris (FWD) was significantly greater in second-growth forest but was a very small biomass component (1-2 Mg/ ha) in both old- and second-growth forests. Coarse woody debris was the only biomass pool that differed substantially and significantly between second- and old-growth forest; it was $4 \times$ greater in the old- compared to the second-growth forests (Fig. 3, Table 2).

Although mean litterfall and forest floor mass were similar between the old-growth and second-growth forest, there were significant differences among individual stands (Table 2). Litterfall mass varied between $2.5 \mathrm{Mg}$ / ha and $4.2 \mathrm{Mg} / \mathrm{ha}$ among individual stands. Forest floor mass varied $>10 \times(4.2-48.5 \mathrm{Mg} / \mathrm{ha})$. Among the six stands, we observed a significant, linear relationship between litterfall mass and forest floor mass ( $r=0.96$, $P=0.004)$.

Nitrogen pools in living and detrital biomass averaged $1200 \pm 142 \mathrm{~kg} \mathrm{~N} /$ ha in old-growth and $950 \pm$ $169 \mathrm{~kg} \mathrm{~N} / \mathrm{ha}$ in second-growth forests (Fig. 4). The difference in $\mathrm{N}$ content between old- and secondgrowth forests resulted largely from the greater quantities of detrital $\mathrm{N}$ found in old-growth forests. Nitrogen content of detrital biomass (sum of standing dead trees, 
TABLE 2. Living and detrital biomass in old- and second-growth northern hardwood forest stands in western Upper Michigan.

\begin{tabular}{|c|c|c|c|c|}
\hline \multirow[b]{3}{*}{ Category } & \multirow{2}{*}{\multicolumn{2}{|c|}{ Biomass (Mg/ha) }} & \multicolumn{2}{|c|}{$F$ values } \\
\hline & & & \multirow{2}{*}{$\begin{array}{c}\text { Age } \\
(\mathrm{df}=1)\end{array}$} & \multirow{2}{*}{$\begin{array}{l}\text { Stand }\{\text { Age }\} \\
(\mathrm{df}=4)\end{array}$} \\
\hline & Old growth & Second growth & & \\
\hline Overstory trees & $262(16.2)$ & $230(6.6)$ & 3.32 & 0.51 \\
\hline Standing dead trees & $28(10.3)$ & $17(3.8)$ & 1.00 & 1.87 \\
\hline Coarse woody debris & $26(4.2)$ & $6(1.2)$ & $20.10 *$ & 0.50 \\
\hline Find woody debris & $1(0.1)$ & $2(0.3)$ & $18.74 *$ & 0.55 \\
\hline Forest floor & $26(9.9)$ & $24(13.0)$ & 0.01 & $11.64 * *$ \\
\hline Annual litterfall & $3.3(0.44)$ & $3.5(0.35)$ & 1.05 & $4.67 * *$ \\
\hline Fine roots & $3.6(0.54)$ & $2.3(0.28)$ & 1.68 & $11.68 * *$ \\
\hline Living + Detrital $\dagger$ & $350(6)$ & $280(11)$ & & \\
\hline
\end{tabular}

Notes: $F$ values and significance levels are results of ANOVA testing effects of forest age (old growth vs. second growth). Stands are nested as random effects within forest age. Standard errors of the mean are in parentheses, $n=3$ stands

$* P<0.05 ; * * P<0.01$.

$\dagger$ Sum of measured biomass components in second- and old-growth stands. Living + detrital pool does not include biomass contained in soil organic matter, coarse roots, or fine roots deeper than $15 \mathrm{~cm}$ from forest floor surface.

CWD, FWD, forest floor (Oe and Oa horizons), and litterfall) was significantly greater in old-growth (560 $\mathrm{kg} \mathrm{N} / \mathrm{ha}$ ) than second-growth (400 kg N/ha) forests, because of five times greater $\mathrm{N}$ in CWD in old growth.

\section{Gross nitrogen transformations}

Gross $\mathrm{N}$ mineralization was almost two times greater in old-growth than in second-growth forests (Table 3 ).
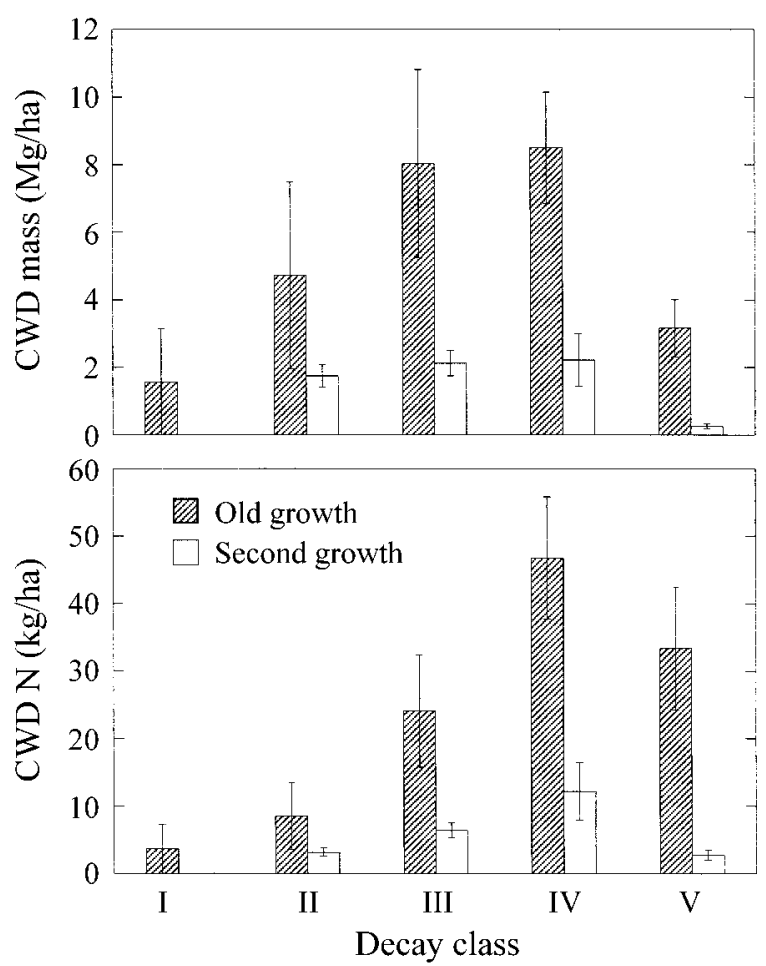

FIG. 3. Coarse woody debris mass and nitrogen in oldand second-growth northern hardwood forest ecosystems in western Upper Michigan. Decay class progresses from I (least decayed) to $\mathrm{V}$ (most highly decayed). Data are means \pm 1 SE; $n=3$ stands.
Variation among stands was high and this difference was only marginally significant given our sampling design (Table $3 ; P=0.06$ ). Gross nitrification did not differ between old- and second-growth forests (Table 3 ), but it accounted for a higher proportion of gross mineralization in second-growth (41\% of gross $\mathrm{N}$ mineralization) compared to old-growth (12\%).

Total microbial immobilization $\left(\mathrm{NH}_{4}{ }^{+}+\mathrm{NO}_{3}{ }^{-}\right)$was significantly greater in old- than second-growth forests, whether estimated either as the sum of $\mathrm{NH}_{4}{ }^{+}$and $\mathrm{NO}_{3}{ }^{-}$ consumption minus gross nitrification or as the difference between gross and net $\mathrm{N}$ mineralization (Table 3 ). Moreover, rates of microbial immobilization of $\mathrm{N}$ exceeded rates of gross $\mathrm{N}$ mineralization in old-growth forests, whereas $\mathrm{N}$ immobilization was similar or less than gross $\mathrm{N}$ mineralization second-growth forests (Table 3). Ammonium was immobilized to a much greater extent than $\mathrm{NO}_{3}{ }^{-}$in both old- and second-growth forests (Table 3). Microbial immobilization of $\mathrm{NO}_{3}{ }^{-}$was

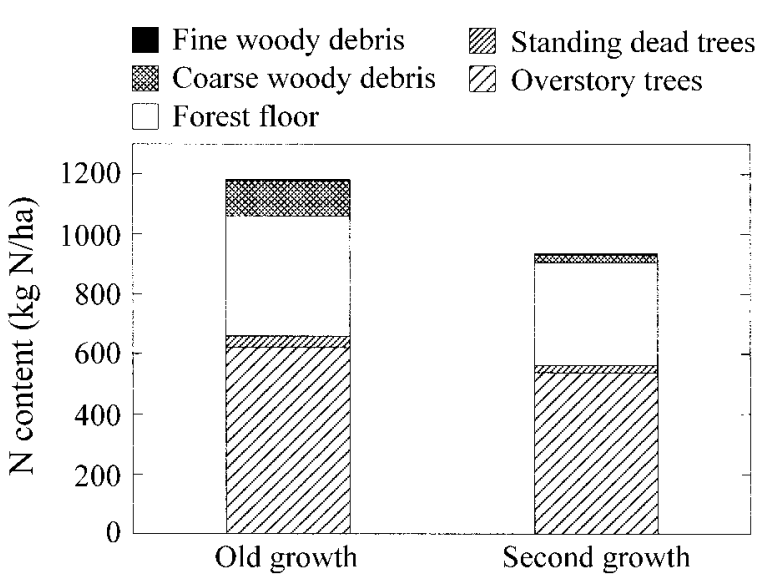

FIG. 4. Nitrogen $(\mathrm{kg} / \mathrm{ha})$ contained in living and detrital biomass in old- and second-growth northern hardwood forests. Values are means for three replicate forest stands. 
TABLE 3. Nitrogen fluxes and pools in old- and second-growth northern hardwood forest soils (from surface of Oe to 15-cm depth), July 1995.

\begin{tabular}{|c|c|c|c|c|}
\hline Measure & Old growth & Second growth & $\begin{array}{c}\text { Age } \\
(\mathrm{df}=1)\end{array}$ & $\begin{array}{l}\text { Stand }\{\text { Age }\} \\
(\mathrm{df}=4)\end{array}$ \\
\hline Gross $\mathrm{N}$ mineralization & $3.7(0.57)$ & $2.1(0.31)$ & 6.57 & 1.00 \\
\hline Gross nitrification & $0.4(0.21)$ & $0.9(0.11)$ & 2.42 & 2.47 \\
\hline $\begin{array}{l}\text { Microbial immobilization } \\
\mathrm{NH}_{4}^{+} \\
\mathrm{NO}_{3}^{-} \\
\text {Total } \mathrm{N} \dagger \\
\text { Total } \mathrm{N}^{-}\end{array}$ & $\begin{array}{l}4.2(0.81) \\
0.2(0.9) \\
4.4(0.93) \\
4.4(1.31)\end{array}$ & $\begin{array}{l}1.6(0.45) \\
0.2(0.10) \\
1.8(0.98) \\
0.5(1.13)\end{array}$ & $\begin{array}{l}5.29 \\
3.35 \\
\text { ND } \\
9.92 *\end{array}$ & $\begin{array}{l}1.06 \\
3.09 \\
\text { ND } \\
1.54\end{array}$ \\
\hline $\begin{array}{l}\text { Microbial N } \\
\text { Residence time }\end{array}$ & $\begin{array}{ll}89 & (11.2) \\
25 & \end{array}$ & $\begin{aligned} 102 & (8.5) \\
59 & \end{aligned}$ & 1.84 & 2.31 \\
\hline
\end{tabular}

Notes: Data show gross $\mathrm{N}$ transformation rates $\left(\mathrm{kg} \mathrm{N} \cdot \mathrm{ha}^{-1} \cdot \mathrm{d}^{-1}\right)$, microbial biomass $\mathrm{N}(\mathrm{kg} \mathrm{N} /$ ha), and $\mathrm{N}$ residence time (in days). The last two columns show results ( $F$ values and significance levels) of ANOVA testing effects of forest age (old-growth vs. second-growth). Stands are nested as random effects within forest age. Standard errors of the means are in parentheses; $n$ $=3$ stands; ND $=$ not determined.

$* P<0.05$.

$\dagger$ Calculated as $\mathrm{NH}_{4}{ }^{+}$consumption - gross nitrification $+\mathrm{NO}_{3}{ }^{-}$consumption.

\$ Calculated as gross $\mathrm{N}$ mineralization - net $\mathrm{N}$ mineralization.

similar between old- and second-growth forest and was a greater proportion of total $\mathrm{N}$ immobilization in second-growth $(11 \%)$ than old-growth $(4 \%)$ forests. The microbial N pool was similar between old- and secondgrowth forests (Table 3 ).

Rates of soil $\mathrm{N}$ transformations can be used to estimate the residence or turnover time of $\mathrm{N}$ in soil pools (Davidson et al. 1992). In both old- and second-growth forests, the daily input of $\mathrm{NH}_{4}{ }^{+}$from gross $\mathrm{N}$ mineralization was similar to the average extractable soil $\mathrm{NH}_{4}{ }^{+}$pool; gross nitrification $\left(\mathrm{NO}_{3}{ }^{-}\right.$input $)$also was similar to the extractable soil $\mathrm{NO}_{3}{ }^{-}$pool. Mean residence times (MRT) for both $\mathrm{NH}_{4}{ }^{+}$and $\mathrm{NO}_{3}{ }^{-}$thus were $\sim 1 \mathrm{~d}$ and did not differ between old- and secondgrowth forests. In contrast, $\mathrm{N}$ residence time in the microbial pool (microbial N/N immobilization) was two times longer in second-growth (59 d) compared to old-growth forest (25 d; Table 3 ).

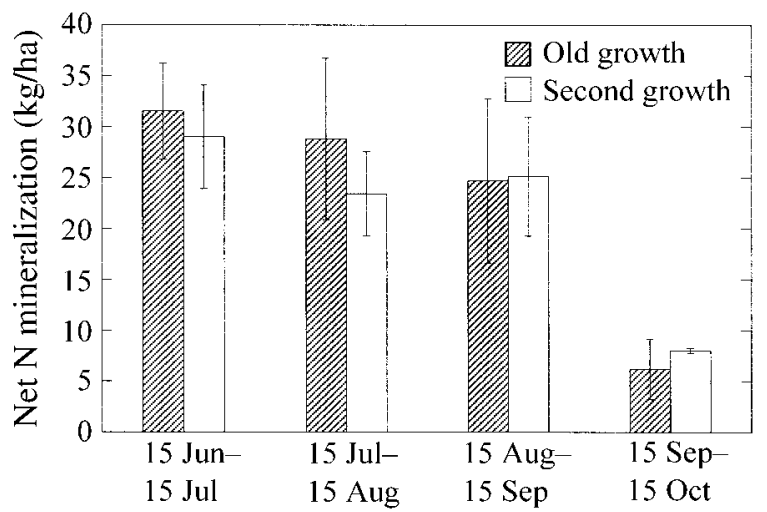

FIG. 5. Net nitrogen mineralization in old-growth and second-growth forest ecosystems using monthly in situ buriedbag incubations throughout the snow-free season, 1995. Data are means $\pm 1 \mathrm{SE} ; n=3$ stands.

\section{In situ net nitrogen transformations}

Monthly in situ net $\mathrm{N}$ mineralization and nitrification varied up to fourfold among stands and also differed over time, with lower rates in the fall compared to the summer months (Fig. 5). Expressed on an areal basis and summed over the snow-free season, mean net $\mathrm{N}$ mineralization and nitrification were similar in old- and second-growth forest (Table 4). However, annual net $\mathrm{N}$ mineralization varied from 44 to $129 \mathrm{~kg} \mathrm{~N} / \mathrm{ha}$ among stands, independent of stand age. Net nitrification followed the same pattern and accounted for a high proportion of net $\mathrm{N}$ mineralized in forests of both ages (Table 4).

Despite the similarity between net $\mathrm{N}$ mineralization and nitrification, patterns of extractable soil $\mathrm{NH}_{4}{ }^{+}$and $\mathrm{NO}_{3}{ }^{-}(0-15 \mathrm{~cm}$ depth) differed from each other. Extractable $\mathrm{NH}_{4}{ }^{+}$varied from 1.8 to $6.2 \mathrm{~kg} \mathrm{~N} / \mathrm{ha}$ and did not differ between old- and second-growth soils or among individual stands. Extractable $\mathrm{NO}_{3}{ }^{-}$concentrations were far lower than $\mathrm{NH}_{4}{ }^{+}(0.1-2.5 \mathrm{~kg} \mathrm{~N} / \mathrm{ha})$, and differed significantly among individual stands. Across stands, average growing season soil $\mathrm{NO}_{3}{ }^{-}$was significantly correlated with litterfall $\mathrm{N}$ flux $(r=0.80, P<$ $0.05)$ and forest floor $\mathrm{N}(r=0.90, P<0.01)$.

\section{Nitrogen leaching}

Nitrate in soil solution at 1-m depth differed significantly among stands, varying from 0.02 to $6.0 \mathrm{mg} \mathrm{N} /$ $\mathrm{L}$, but did not differ between second- and old-growth forest (Table 5). Dissolved organic N (DON) concentrations were less variable (0.02-1.2 mg N/L), differing neither among stands nor between old- and secondgrowth forests (Table 5). As a result, soil solution $\mathrm{N}$ was not consistently dominated by one form of N. Nitrate varied among stands from $15 \%$ to $80 \%$ of total soil solution $\mathrm{N}$. 
TABLE 4. Total net $\mathrm{N}$ mineralization and nitrification ( $\mathrm{kg} \mathrm{N} / \mathrm{ha}$ ) measured in monthly in situ forest soil incubations (from surface of Oe to $15 \mathrm{~cm}$ depth) from 15 June to 15 October 1995.

\begin{tabular}{lllcc}
\hline \hline \multicolumn{1}{c}{ Measure } & $\begin{array}{c}\text { Old } \\
\text { growth }\end{array}$ & $\begin{array}{c}\text { Second } \\
\text { growth }\end{array}$ & $\begin{array}{c}\text { Age } \\
(\mathrm{df}=1)\end{array}$ & $\begin{array}{c}\text { Stand }\{\text { Age }\} \\
\mathrm{df}=4\end{array}$ \\
\hline Net N mineralization & $93(25.5)$ & $91(17.9)$ & 0.03 & $17.82^{* *}$ \\
Net nitrification & $70(23.5)$ & $79(14.0)$ & 0.01 & $13.97 * *$ \\
Net nitrification as a percentage & $75(2.8)$ & $87(3.0)$ & $9.09 * *$ & $3.17^{*}$ \\
$\quad$ of net N mineralization & & & & \\
\hline
\end{tabular}

Notes: The last two columns show results ( $F$ values and significance levels) of ANOVA testing effects of forest age (old growth vs. second growth). Stands are nested as random effects within forest age. Standard errors of the means are in parentheses; $n=3$ stands.

$* P<0.05 ; * * P<0.01$.

No seasonal trends were evident in soil solution $\mathrm{N}$ concentrations. However, water flux estimates differed substantially between growing season (June-October) and nongrowing season (April, May, November) months. We therefore found a pronounced seasonal pattern of $\mathrm{N}$ leaching, with the largest quantities during snowmelt (April and May), and after leaf fall (November) (Figs. 6 and 7).

Leaching loss of inorganic plus organic $\mathrm{N}$ averaged $1.8 \mathrm{~kg} \mathrm{~N} \cdot \mathrm{ha}^{-1} \cdot \mathrm{yr}^{-1}$ in old-growth and $2.8 \mathrm{~kg} \mathrm{~N} \cdot \mathrm{ha}^{-1} \cdot \mathrm{yr}^{-1}$ in second-growth forests and over both years (Table 6). Consistent with soil solution $\mathrm{N}$ concentrations, leaching did not differ between forest ages. These average estimates of $\mathrm{N}$ leaching were less than wet deposition of $\mathrm{N}$ to the nearby $(45 \mathrm{~km})$ Trout Lake NADP monitoring site (Table 6). Significant differences in leaching losses existed among forest stands, which ranged from 0.6 to $5.2 \mathrm{~kg} \mathrm{~N} / \mathrm{ha}$ in 1996 and from 0.7 to $5.6 \mathrm{~kg} \mathrm{~N} / \mathrm{ha}$ in 1997 . Wet deposition of $\mathrm{N}$ exceeded

TABle 5. Nitrogen concentrations $(\mathrm{mg} / \mathrm{L})$ in soil solution sampled monthly in old- and second-growth northern hardwood forests.

\begin{tabular}{lcclll}
\hline \hline & \multicolumn{2}{c}{1996} & & \multicolumn{2}{c}{1997} \\
\cline { 2 - 3 } \cline { 5 - 6 } Month & $\begin{array}{c}\text { Old } \\
\text { growth }\end{array}$ & $\begin{array}{c}\text { Second } \\
\text { growth }\end{array}$ & & $\begin{array}{c}\text { Old } \\
\text { growth }\end{array}$ & $\begin{array}{c}\text { Second } \\
\text { growth }\end{array}$ \\
\hline Nitrate & & & & & \\
Apr & $0.8(0.35)$ & $1.5(0.76)$ & & $0.9(0.44)$ & $1.1(0.58)$ \\
May & $0.8(0.33)$ & $1.6(1.06)$ & & $0.9(0.43)$ & $1.6(1.01)$ \\
Jun & $1.0(0.33)$ & $1.2(0.68)$ & & $0.7(0.35)$ & $2.5(1.60)$ \\
Jul & $0.7(0.28)$ & $1.1(0.62)$ & & $0.9(0.42)$ & $2.2(1.40)$ \\
Aug & $0.5(0.21)$ & $1.0(0.53)$ & & $0.9(0.48)$ & $1.7(0.95)$ \\
Sep & $0.4(0.21)$ & $1.0(0.53)$ & & $0.9(0.40)$ & $1.4(0.85)$ \\
Oct & $0.8(0.48)$ & $1.5(0.46)$ & & $0.2(0.16)$ & $1.2(0.57)$ \\
Nov & $0.9(0.52)$ & $1.6(0.60)$ & & ND & ND \\
Dissolved organic N & & & & & \\
Apr & $0.3(0.01)$ & $0.2(0.04)$ & & $0.6(0.09)$ & $0.4(0.08)$ \\
May & $0.3(0.11)$ & $0.5(0.08)$ & & $0.5(0.04)$ & $0.5(0.10)$ \\
Jun & $0.2(0.09)$ & $0.1(0.10)$ & & $0.3(0.10)$ & $0.3(0.05)$ \\
Jul & $0.4(0.06)$ & $0.2(0.07)$ & & $0.3(0.05)$ & $0.4(0.14)$ \\
Aug & $0.5(0.04)$ & $0.3(0.07)$ & & $0.5(0.15)$ & $0.4(0.06)$ \\
Sep & $0.8(0.21)$ & $0.9(0.19)$ & & $0.1(0.02)$ & $0.2(0.05)$ \\
Oct & $0.7(0.16)$ & $0.5(0.15)$ & & $0.4(0.09)$ & $0.4(0.07)$ \\
Nov & $0.3(0.06)$ & $0.4(0.01)$ & ND & ND \\
\hline
\end{tabular}

Notes: Standard errors of the means are in parentheses; $n$ $=3$ stands. ND indicates not determined because lysimeters collected no soil solution. leaching from all individual forest stands except S-2, which leached $5.6 \mathrm{~kg} \mathrm{~N} / \mathrm{ha}$ in 1997.

These comparisons of leaching loss to wet deposition depend upon the accuracy of our water flux estimates. Although we cannot verify these estimates or even estimate variability in water flux through our soil profiles, we did estimate potential error in the model by varying soil and canopy parameters. Our manipulation of canopy (height and LAI) or soil (type, depth, and organic matter content) parameters produced at most $20 \%$ variation in water flux, which should far exceed the relatively small variation in these parameters that occurs within our stands or between old- and second-growth forests. This maximum potential error corresponds to $\mathrm{N}$ leaching of $\pm 0.4 \mathrm{~kg} \mathrm{~N} \cdot \mathrm{ha}^{-1} \cdot \mathrm{yr}^{-1}$ in old-growth and $\pm 0.6 \mathrm{~kg} \mathrm{~N} \cdot \mathrm{ha}^{-1} \cdot \mathrm{yr}^{-1}$ in second-growth forests. With the

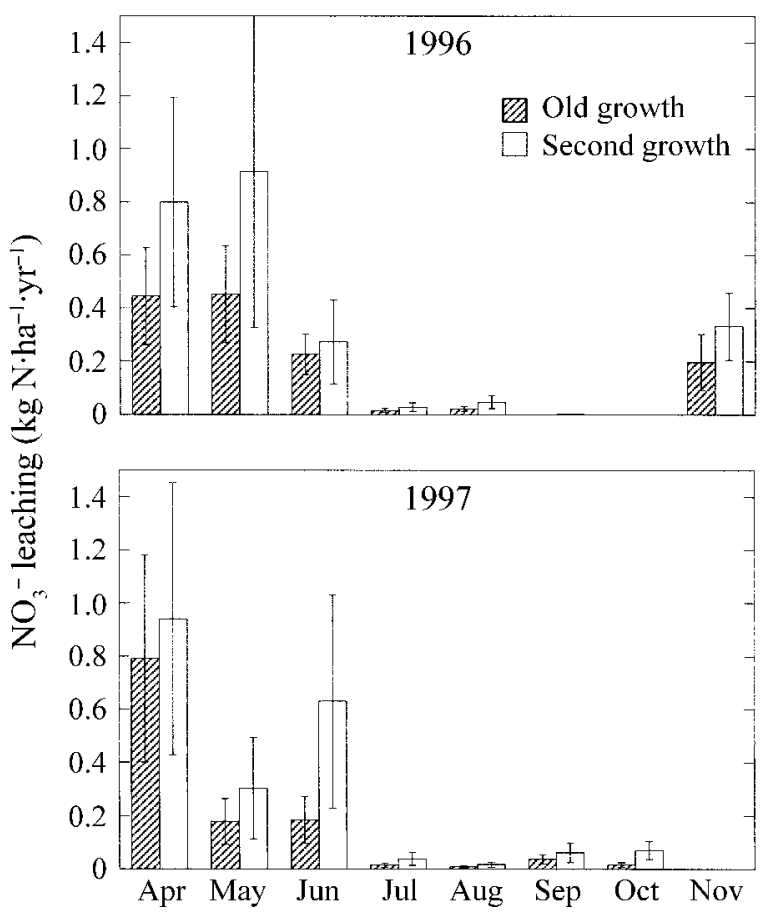

FIG. 6. Nitrate leaching ( $\mathrm{kg} \mathrm{N} / \mathrm{ha})$ at $1-\mathrm{m}$ depth in oldgrowth and second-growth forest stands in 1996 and 1997. Data are means $\pm 1 \mathrm{SE} ; n=3$ stands. 


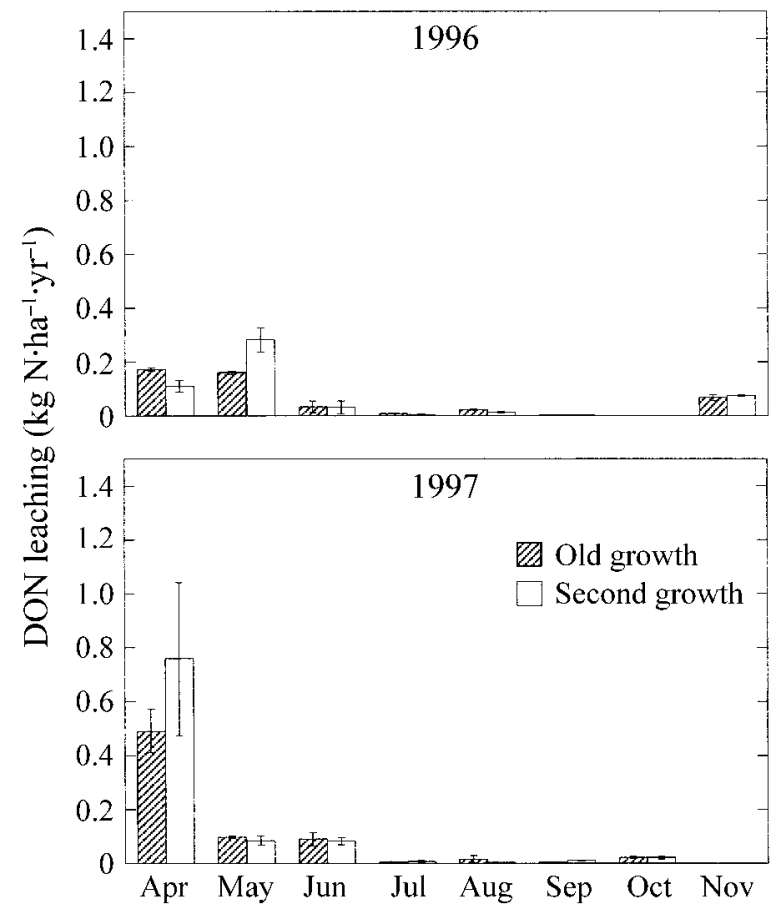

FIG. 7. Dissolved organic nitrogen (DON; kg N/ha) at 1$\mathrm{m}$ depth in old-growth and second-growth forest stands in 1996 and 1997. Data are means \pm 1 SE; $n=3$ stands.

exception of stand $\mathrm{S}-2$, these potential errors are not large enough to suggest net $\mathrm{N}$ loss from these forest stands.

The pattern of $\mathrm{N}$ loss from individual stands paralleled that of several ecosystem pools and $\mathrm{N}$ cycling variables. Nitrate leaching loss from each stand was significantly and positively related to average growing season extractable soil $\mathrm{NO}_{3}^{-}$(in surface $15 \mathrm{~cm} ; r=$ 0.96; $P=0.004$; Fig. 8A), litterfall N flux $(r=0.91$; $P=0.01$; Fig. 8B), and forest floor N $(r=0.83 ; P=$ $0.04)$. Nitrate leaching showed a significant negative relationship with fine root biomass $(r=-0.88, P=$ 0.02 ; Fig. $8 \mathrm{C}$ ). Nitrate leaching was not significantly related to net $\mathrm{N}$ mineralization, primarily because of the very high $\mathrm{NO}_{3}{ }^{-}$leaching from stand S-2 (Fig. 8D). Excluding this point from the analysis resulted in a significant positive relationship between net $\mathrm{N}$ mineralization and $\mathrm{NO}_{3}{ }^{-} \operatorname{loss}(r=0.99 ; P=0.0002)$, growing season extractable soil $\mathrm{NO}_{3}{ }^{-}(r=0.93 ; P=$ $0.02)$, and litterfall $\mathrm{N}$ flux $(r=0.88, P=0.05)$. Nitrate leaching was not related to $\mathrm{N}$ pools or transformations that differed between old- and second-growth forests. For instance, no relationships were evident between $\mathrm{NO}_{3}{ }^{-}$leaching and gross $\mathrm{N}$ immobilization rates (Fig. 8E) or $\mathrm{N}$ in CWD (Fig. 8F).

\section{DISCUSSION}

We investigated the linkages among $\mathrm{N}$ storage, $\mathrm{N}$ cycling processes, and $\mathrm{N}$ leaching losses in this comparison of $\mathrm{N}$ retention between uneven-aged old- growth and even-aged second-growth northern hardwood forests in western Upper Michigan. Our exploration of relationships among different aspects of ecosystem $\mathrm{N}$ cycling provides insights into patterns of $\mathrm{N}$ cycling that differ between successional stages and contribute to ecosystem $\mathrm{N}$ storage vs. those that are not age dependent, but rather covary strongly across sites and are predictive of $\mathrm{N}$ leaching losses. We did not find differences in net $\mathrm{N}$ retention between old- and second growth forest ecosystems, and we found only partial support for our general hypothesis that the accumulation of detrital biomass in old-growth northern hardwood forests creates a heterotrophic $\mathrm{N}$ sink that leads to lower $\mathrm{N}$ leaching losses than those from maturing second-growth hardwoods. While our findings did suggest that rapid rates of microbial $\mathrm{N}$ turnover and the incorporation of $\mathrm{N}$ into woody detritus create a heterotrophic sink for $\mathrm{N}$ late in forest ecosystem succession, this potential $\mathrm{N}$ sink did not correspond with patterns of net $\mathrm{N}$ retention.

Patterns of $\mathrm{N}$ storage and microbial $\mathrm{N}$ immobilization also did not correspond with other indicators of internal $\mathrm{N}$ cycling in our study sites. Net $\mathrm{N}$ mineralization and litterfall $\mathrm{N}$ did not differ between old- and second-growth forests, contrary to our hypothesis that microbial $\mathrm{N}$ demand would limit the availability of inorganic $\mathrm{N}$ to a greater extent in old-growth forest. Although our results did not support the idea that slower net $\mathrm{N}$ mineralization and nitrification rates limit $\mathrm{NO}_{3}{ }^{-}$leaching losses to a greater extent from oldgrowth than from second-growth forests, they did suggest that processes leading to available $\mathrm{NO}_{3}{ }^{-}$pools regulated $\mathrm{NO}_{3}{ }^{-}$leaching losses among the forest stands that we studied. The primary control of $\mathrm{N}$ leaching from these individual forest stands appears to be related to stand-specific rates of net $\mathrm{N}$ cycling that are not dependent on forest age.

TABLE 6. Nitrogen leaching losses $\left(\mathrm{kg} \mathrm{N} \cdot \mathrm{ha}^{-1} \cdot \mathrm{yr}^{-1}\right)$ and retention in old- and second-growth northern hardwood forests.

\begin{tabular}{lcc}
\hline \hline \multicolumn{1}{c}{ Measure } & Old growth & Second growth \\
\hline 1996 & & \\
Total dissolved N & $1.6(0.55)$ & $2.8(1.29)$ \\
$\mathrm{NO}_{3}^{-}-\mathrm{N}$ & $1.4(0.54)$ & $2.4(1.28)$ \\
Input - Leaching & 3.9 & 2.7 \\
$\mathrm{~N}$ input retained (\%) & 71 & 51 \\
1997 & $2.0(0.77)$ & $2.8(1.42)$ \\
Total dissolved N & $1.2(0.59)$ & $2.1(1.20)$ \\
$\mathrm{NO}_{3}^{-}-\mathrm{N}$ & 1.5 & 0.7 \\
Input - Leaching & 20 \\
$\mathrm{~N}$ input retained $(\%)$ & 43 &
\end{tabular}

Notes: Total dissolved $\mathrm{N}$ is the sum of $\mathrm{NO}_{3}{ }^{-}-\mathrm{N}$ and dissolved organic N. Retention was estimated as the difference between losses and annual wet deposition inputs of $5.5 \mathrm{~kg}$ $\mathrm{N} \cdot \mathrm{ha}^{-1} \cdot \mathrm{yr}^{-1}$ in 1996 and $3.5 \mathrm{~kg} \mathrm{~N} \cdot \mathrm{ha}^{-1} \cdot \mathrm{yr}^{-1}$ in 1997 (data courtesy of National Atmospheric Deposition Program (NRSP-3)/National Trends Network [1999], Trout Lake field station). Standard errors of the means are in parentheses, $n$ $=3$ stands. 

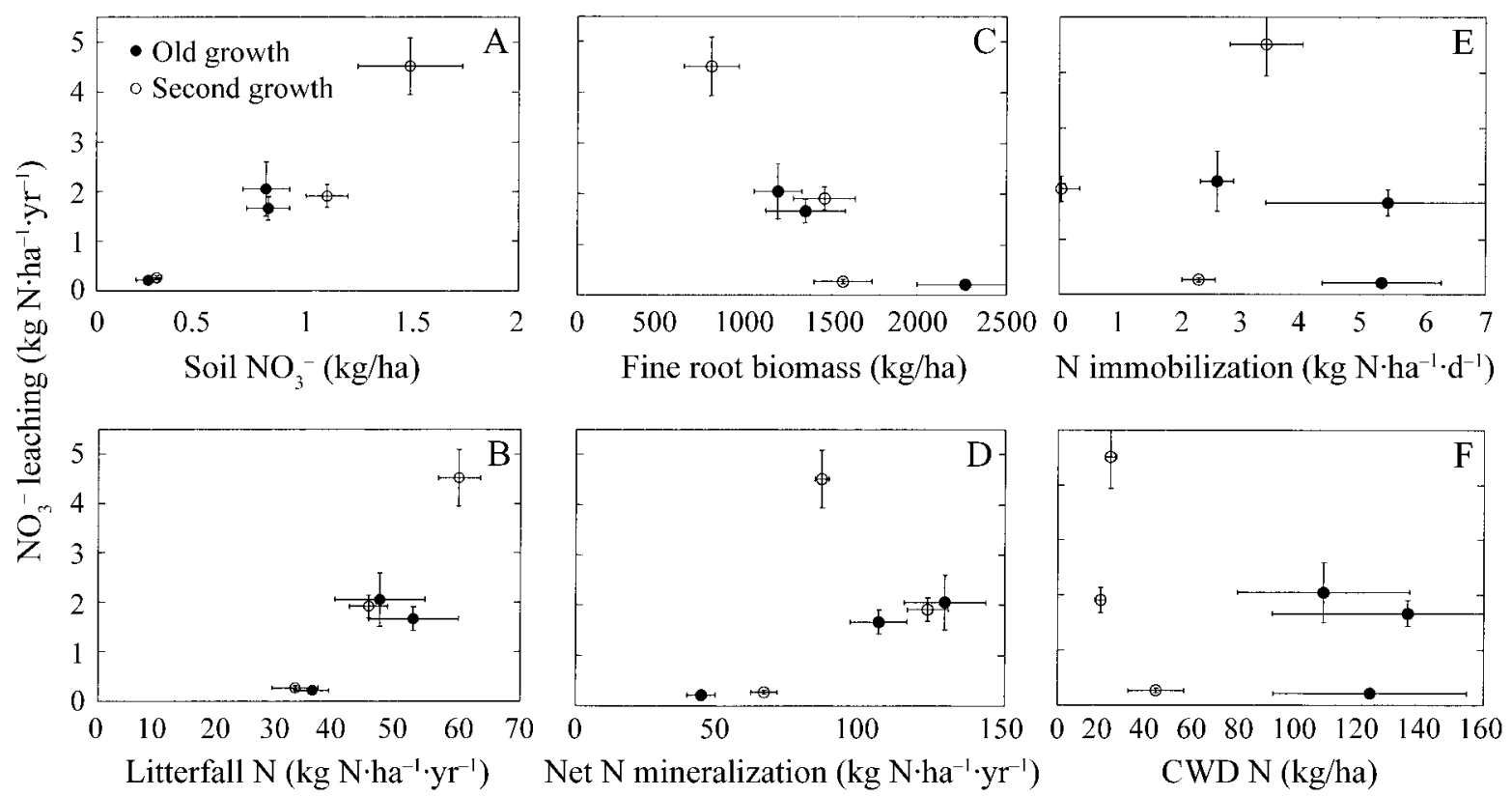

FIG. 8. Relationships between mean $\mathrm{NO}_{3}{ }^{-}-\mathrm{N}$ losses in 1996 and 1997 and (A) extractable soil $\mathrm{NO}_{3}{ }^{-}$pools (mean for growing season 1995), (B) litterfall $\mathrm{N}$ flux (1995), (C) fine root biomass (average, midsummer 1995 and 1996), (D) net $\mathrm{N}$ mineralization (1995), (E) gross N immobilization (July 1995), and (F) N contained in coarse woody debris, for three oldgrowth and three second-growth northern hardwood forests. Error bars are standard errors of within-stand means; $n=8$ replicates for $\mathrm{NO}_{3}{ }^{-}-\mathrm{N}$ leaching; 6 replicates for soil $\mathrm{NO}_{3}{ }^{-}$, fine root biomass, leaf litterfall, and net $\mathrm{N}$ mineralization; and 3 replicates for gross $\mathrm{N}$ immobilization and $\mathrm{N}$ in coarse woody debris.

\section{Biomass and nitrogen pools}

Despite differences in successional development that were evident from overstory structure, second growth had accumulated an average of $88 \%$ of the overstory biomass found in old-growth forests, and neither overstory biomass nor $\mathrm{N}$ differed significantly between oldand second-growth forests. Our observations contrast with some predictions suggesting that overstory biomass can accumulate for well over $100 \mathrm{yr}$ after harvest of northern hardwood forests (Botkin et al. 1972, Bormann and Likens 1979), but they concur with more recent evidence that overstory biomass in northern hardwood forests can attain maximum values in as little as $80 \mathrm{yr}$ (Likens et al. 1994). Although we did not quantify coarse structural roots, results of Whittaker et al. (1974) indicate that coarse roots are $\sim 20 \%$ of overstory biomass in northern hardwood forests. Based on this average estimate, total biomass in overstory trees averaged $310 \mathrm{Mg} / \mathrm{ha}$ in old-growth and $280 \mathrm{Mg} / \mathrm{ha}$ in second-growth forests. However, Whittaker et al. (1974) also found that the contribution of coarse roots to total biomass increased with tree size. We may have therefore underestimated coarse root biomass in our old-growth forests, compared to second growth. Our estimates of plant biomass also lack the understory component. This is likely to be small (3\% of total in second growth [Crow et al. 1991]), but would nevertheless further increase the difference between old- and second-growth biomass and $\mathrm{N}$ content. Crow et al.
(2001) found four times the stem density of woody understory plants in the old-growth compared to the second-growth stands that we studied.

We were particularly interested in the biomass of detrital components because of their potential to influence microbial activity and ecosystem $\mathrm{N}$ storage. We found more detrital biomass in old-growth forests, primarily due to greater mass of coarse woody debris. These results are consistent with the idea that nonliving biomass becomes a greater proportion of total biomass as forests mature (Gorham et al. 1979, Vitousek et al. 1988). Furthermore, the $\mathrm{N}$ content of detrital biomass is generally greater than $\mathrm{N}$ in living biomass, because $\mathrm{N}$ is immobilized in detritus (Schimel and Firestone 1989b, Hart et al. 1993) and conserved during wood decomposition (Harmon et al. 1986). Accordingly, we found a greater biomass $\mathrm{N}$ capital in old-growth forests, primarily due to $\mathrm{N}$ in standing dead trees and CWD. Together these pools totaled $160 \mathrm{~kg} \mathrm{~N} / \mathrm{ha}$ in old-growth forest and $50 \mathrm{~kg} \mathrm{~N} / \mathrm{ha}$ in second-growth forest. Forest floor mass or $\mathrm{N}$ did not differ between old- and secondgrowth, concurring with Covington's (1981) model of forest floor recovery following forest harvest.

Sollins et al. (1980) concluded that tree mortality in old-growth Douglas-fir represented an organic matter input to soil equal in quantity to aboveground litterfall, and our data indicate that CWD inputs are of similar importance in old-growth northern hardwood forests. We used the relationship $I=C_{e} k$; where $I$ is CWD 
inputs, $C_{e}$ is CWD mass at equilibrium, and $k$ is the first-order decay constant (Jenny et al. 1949, Sollins et al. 1980), to estimate annual CWD production required to sustain the current pool size in old-growth forest. We assumed that CWD was close to equilibrium and was no longer accumulating in old-growth forest. Based on the distribution of CWD among decay classes in our study (Fig. 3), this assumption is consistent with the model of Tyrrell and Crow (1994). Decay constants for mass loss in northern hardwood boles vary from $0.080 \mathrm{yr}^{-1}$ for Populus tremuloides in Minnesota (Alban and Pastor 1993) to $0.096 \mathrm{yr}^{-1}$ for Fagus grandifolia, Betula alleghaniensis, and Acer saccharum in New Hampshire (Arthur et al. 1993). Using these decay constants, annual inputs of $2.1-2.5 \mathrm{Mg} / \mathrm{ha}$ are required to maintain current CWD mass $(26.0 \mathrm{Mg} / \mathrm{ha})$ in oldgrowth forest. This estimate, equal to $60-70 \%$ of leaf litterfall, represents an important organic matter input in the old-growth forests.

Such an estimate is not possible for second-growth forests, because CWD is relatively low and will likely increase fourfold as these forests attain old-growth status. Nevertheless, it is apparent that our second-growth forests have accumulated CWD at a slow rate. Our observation of $6.0 \mathrm{Mg} / \mathrm{ha} \mathrm{CWD}$ in second growth was far lower than values from 50- to 100-yr-old northern hardwoods in the northeastern United States $(16.8 \mathrm{Mg}$ / ha [Tritton 1980], 32.1-54.4 Mg/ha [Gore and Patterson 1986]), but was identical to other quantities documented in second-growth Lake States northern hardwoods (Goodburn and Lorimer 1998). Furthermore, the low biomass of standing dead trees in second growth (60\% of that in old growth) suggests that inputs to the second-growth CWD pool will remain low for some period of time. Our second-growth forest ecosystems thus appear to be at a transition point, during which living overstory biomass accumulation is slow but mortality and detrital biomass accumulation are still minimal.

\section{Gross nitrogen transformations}

Substantially greater gross $\mathrm{N}$ immobilization and turnover of $\mathrm{N}$ through microbial biomass in old-growth forests suggest that microbial $\mathrm{N}$ demand is a more important component of $\mathrm{N}$ cycling processes compared to second-growth forests. We made this comparison only once during the year (mid growing season); although we would not expect the relative pattern between old- and second-growth forests to change dramatically, further investigation of seasonality would be informative for more in-depth comparison of microbial $\mathrm{N}$ cycling between old- and second-growth forests. Nevertheless, our results concur with comparisons between old- and second-growth conifer forests (Davidson et al. 1992). High microbial $\mathrm{N}$ demand also has been suggested by an increase in microbial $\mathrm{N}$ following $\mathrm{N}$ additions in old-growth conifer forests (Hart and Stark 1997). Davidson et al. (1992) and Hart et al. (1994a) proposed that labile $\mathrm{C}$ availability regulated $\mathrm{NO}_{3}{ }^{-}$immobilization in conifer-dominated old-growth forests. The possibility that the same is true for $\mathrm{NH}_{4}{ }^{+}$ and $\mathrm{NO}_{3}{ }^{-}$immobilization warrants further study in these northern hardwood forests. It is also possible that microbial activity and $\mathrm{N}$ immobilization respond to the greater annual inputs of $\mathrm{C}$ in woody detritus in the oldgrowth forests.

Microbial $\mathrm{N}$ uptake and turnover has been proposed as an important pathway for $\mathrm{N}$ sequestration in forest floor or soil organic matter (Couteaux and Sallih 1994, Magill et al. 1997, Seely and Lajtha 1997). Experimental tracer studies have shown $\mathrm{N}$ uptake by soil microbial biomass, followed by incorporation in soil organic matter to varying degrees (Hart et al. 1993, Stark and Hart 1997, Zogg et al. 2000, Perakis and Hedin 2001). Although the total quantity of $\mathrm{N}$ cycled to organic matter varies among forests, it is likely to be a substantial longterm sink, as organic matter can slowly accumulate in forest soils long after overstory biomass reaches a maximum (Schlesinger 1977). Mechanisms that regulate microbial $\mathrm{N}$ uptake and turnover deserve further attention for understanding changes in the function of soil microorganisms late in forest succession, especially the movement of $\mathrm{N}$ from microbial biomass into stable forms of soil organic matter with long turnover times.

In addition to possibly sequestering $\mathrm{N}$ in organic forms, microbial immobilization of $\mathrm{N}$ can limit $\mathrm{N}$ losses by limiting nitrification and thus quantities of $\mathrm{NO}_{3}^{-}$ in the available soil pool. We found that more rapid rates of $\mathrm{NH}_{4}{ }^{+}$immobilization in old-growth forests did correspond to lower gross nitrification (12\% of gross mineralization in old-growth forests, compared to $41 \%$ of gross mineralization in second-growth). However, this pattern did not carry through to affect net nitrification rates, available $\mathrm{NO}_{3}^{-}$pools, or $\mathrm{NO}_{3}^{-}$leaching. Instead, we found low rates of $\mathrm{NO}_{3}{ }^{-}$immobilization and similarly high rates of net nitrification in forests of both ages. These results differ from the pathway of microbial transformations that determined net nitrification in conifer forests, where high $\mathrm{NO}_{3}{ }^{-}$immobilization limited net nitrification in old growth relative to second growth (Davidson et al. 1992).

\section{In situ net nitrogen transformations}

Despite greater microbial $\mathrm{N}$ demand in old growth, we did not find differences in net $\mathrm{N}$ mineralization between old- and second-growth forests. Successional patterns of net $\mathrm{N}$ mineralization differ among ecosystems, such that generalization is difficult (Ryan et al. 1997). Some studies suggest that net $\mathrm{N}$ mineralization declines as forest ecosystems mature (Vitousek et al. 1989, Frazer et al. 1990, Binkley et al. 1995), and higher $\mathrm{N}$ immobilization is one mechanism that can lead to lower net $\mathrm{N}$ mineralization in older forests (Davidson et al. 1992). In our study, more rapid $\mathrm{N}$ immobilization in old-growth than second-growth forests 
did not correspond to uniformly lower net $\mathrm{N}$ mineralization, because gross $\mathrm{N}$ mineralization and immobilization varied proportionately among all stands. This produced similar net $\mathrm{N}$ mineralization rates between second- and old-growth forests in our short-term pooldilution incubations, and it is possible that the same was true for monthly net $\mathrm{N}$ mineralization.

Nitrogen mineralization and cycling are known to vary widely among Lake States forests that differ in soil type and overstory composition (Nadelhoffer et al. 1983, Pastor et al. 1984, Zak et al. 1989, Reich et al. 1997). We were surprised to find an equally wide range of net $\mathrm{N}$ mineralization rates among our study sites (40-130 $\mathrm{kg} \mathrm{N} \cdot \mathrm{ha}^{-1} \cdot \mathrm{yr}^{-1}$ ) despite efforts to minimize within-ecosystem variation. Soil organic matter, soil texture, and soil $\mathrm{pH}$ were similar among stands, and soil water content did not differ among stands (data not shown). Overstory species composition varied only slightly, with sugar maple accounting for $61-89 \%$ of total litterfall. One difference among forest stands was the absence of a forest floor horizon in one old-growth and one second-growth stand, which may be related to locally abundant earthworm populations (M. C. Fisk, personal observation). Although our study was not designed to investigate such an influence, these two stands obviously differed in some manner that corresponds to a more conservative pattern of $\mathrm{N}$ cycling, as net $\mathrm{N}$ mineralization, extractable soil $\mathrm{NO}_{3}{ }^{-}$pools, and litterfall $\mathrm{N}$ flux all were lower in these second-growth (S-3) and old-growth (O-3) stands.

\section{Nitrogen leaching}

Atmospheric $\mathrm{N}$ deposition was greater than $\mathrm{N}$ leaching from the forests that we studied, suggesting that these forests retain substantial quantities of N. Our estimates of retention (Table 6) do not include dry deposition or biological $\mathrm{N}$ fixation as inputs; they are therefore conservative. No good estimates of biological $\mathrm{N}$-fixation exist for our study sites, but general estimates for hardwood forests average $\sim 1.5 \mathrm{~kg}$ $\mathrm{N} \cdot \mathrm{ha}^{-1} \cdot \mathrm{yr}^{-1}$ (Cleveland et al. 1999). Furthermore, tension lysimeters can sample water that is more tightly held to soil rather than water that moves through soil in bulk flow (Barbee and Brown 1986, Joslin et al. 1987). Although there is no simple consensus on the accuracy of $\mathrm{N}$ concentrations sampled in porous-cup tension lysimeters (Litaor 1988), it is possible that these samplers overestimate soil solution N concentrations (Hendershot and Courchesne 1991). Any of these factors suggest that we have overestimated $\mathrm{N}$ leaching losses and underestimated $\mathrm{N}$ retention.

Nitrogen retention in these old-growth forests is not consistent with predictions of the nutrient retention hypothesis that $\mathrm{N}$ loss from old-growth forests will equal $\mathrm{N}$ input (Vitousek and Reiners 1975). Our data do not allow us to test whether biomass accumulation has ceased in these forests, an underlying assumption of the nutrient retention hypothesis. Nevertheless, our study contributes to a growing body of literature that points to the need to better understand soil $\mathrm{N}$ sinks, and it suggests that the nutrient retention hypothesis could be augmented with a heterotrophic $\mathrm{N}$ sink whose importance increases late in secondary succession.

The seasonal patterns of $\mathrm{N}$ leaching that we found further emphasize heterotroph regulation of patterns of $\mathrm{N}$ loss. Plant uptake of $\mathrm{N}$ minimizes the availability of $\mathrm{NO}_{3}{ }^{-}$for leaching during the growing season and thus limits total quantities of $\mathrm{N}$ leaching. However, microbial processes regulate $\mathrm{NO}_{3}{ }^{-}$pools available for leaching loss outside of the growing season. In this study, $82 \%$ of $\mathrm{N}$ leaching in old-growth and $88 \%$ of N leaching in second-growth forests occurred in the spring before leafout and in the autumn after leaf fall. Microbial processes that mediate available $\mathrm{NO}_{3}{ }^{-}$pools during these times are therefore critical for determining patterns of $\mathrm{N}$ leaching losses.

We found no differences in $\mathrm{N}$ leaching between oldand second-growth forests; high variability suggests that inherent differences in net $\mathrm{N}$ cycling among stands were greater than any differences that might be related to forest age. Most noteworthy were differences among stands in the dominant form of $\mathrm{N}$ in soil solution. Nitrate was the major component of $\mathrm{N}$ leaching in two old-growth and two second-growth stands, whereas DON composed the majority of $\mathrm{N}$ lost from the remaining two stands ( $\mathrm{S}-3$ and O-3; data not shown). Hedin et al. (1995) noted that N leaching was dominated by DON in old-growth Chilean forests that receive small amounts of atmospheric $\mathrm{N}$ deposition, and Vitousek et al. (1998) suggested that the relative contribution of DON to $\mathrm{N}$ leaching declines as atmospheric $\mathrm{N}$ deposition increases. Because our study sites received a moderate amount of $\mathrm{N}$ deposition $(5 \mathrm{~kg}$ $\mathrm{N} \cdot \mathrm{ha}^{-1} \cdot \mathrm{yr}^{-1}, 4-10 \%$ of annual net $\mathrm{N}$ mineralization), we expected $\mathrm{NO}_{3}{ }^{-}$to be the dominant form of $\mathrm{N}$ leached from soil. Large differences in the contribution of DON to $\mathrm{N}$ leaching within the same $\mathrm{N}$ deposition regime concur with patterns of litterfall $\mathrm{N}$ and soil $\mathrm{NO}_{3}{ }^{-}$to suggest that fundamental differences in $\mathrm{N}$ cycling exist among our forest stands.

\section{Conclusions: relationships among $N$ cycling processes and $N$ retention}

Two patterns emerged in this study of $\mathrm{N}$ dynamics in northern hardwood forests. First, detrital N storage and microbial $\mathrm{N}$ cycling were greater in old-growth than second-growth forests. Second, we found that $\mathrm{N}$ leaching losses corresponded to indicators of plant $\mathrm{N}$ cycling (net $\mathrm{N}$ mineralization and litterfall $\mathrm{N}$ flux) that were independent of forest age, biomass pools, or gross $\mathrm{N}$ transformations at the successional stages that we compared. Ecosystem $\mathrm{N}$ storage thus was distinct from and did not necessarily covary with net $\mathrm{N}$ retention. We conclude that detrital $\mathrm{N}$ storage and microbial $\mathrm{N}$ immobilization probably influence $\mathrm{N}$ leaching from these forests, but that they do not appear to be the 
primary factors limiting $\mathrm{N}$ losses in the forests that we studied. Instead, overall $\mathrm{N}$ cycling rates, indicated by net $\mathrm{N}$ transformations and litterfall $\mathrm{N}$ flux, were more closely related to the wide variation in $\mathrm{N}$ leaching that we found among northern hardwood forests in Upper Michigan. The underlying factors that regulate spatial variation in $\mathrm{N}$ cycling among stands need to be better understood to fully evaluate short- and long-term controls of $\mathrm{N}$ retention in these northern hardwood forest ecosystems.

\section{ACKNOWLEDGMENTS}

Support for this research was provided through a Cooperative Research Agreement between the University of Michigan and the North Central Forest Research Station, U.S. Forest Service, and by the McIntire-Stennis Cooperative Forestry Act. We thank Bob Evans, Watersmeet District, Ottawa National Forest for logistical support and assistance with study site location; and David Buckley, Stephen LeDuc, Angie Luetkenhaus, Dawn Majewski, Dana McDonald, Elizabeth Nauertz, Melissa Piirainen, and Christi Vedejs for assistance in the field and laboratory. We also thank Eric Davidson, Peter Groffman, Joe Yavitt, and anonymous reviewers for insightful discussions and comments that significantly improved the manuscript.

\section{Literature Cited}

Alban, D. H., and J. Pastor. 1993. Decomposition of aspen, spruce, and pine boles on two sites in Minnesota. Canadian Journal of Forest Research 23:1744-1749.

Albert, D. A. 1994. Ecoregion map and classification of Michigan, Minnesota, and Wisconsin. USDA Forest Service General Technical Report NC-178.

Arthur, M. A., L. M. Tritton, and T. J. Fahey. 1993. Dead bole mass and nutrients remaining 23 years after clearfelling of a northern hardwood forest. Canadian Journal of Forest Research 23:1298-1305.

Barbee, G. C., and K. W. Brown. 1986. Comparison between suction and free-drainage soil solution samplers. Soil Science 141:149-154.

Binkley, D., F. W. Smith, and Y. Son. 1995. Nutrient supply and declines in leaf area and production in lodgepole pine. Canadian Journal of Forest Research 25:621-628.

Bormann, F. H., and G. E. Likens. 1979. Pattern and process in a forested ecosystem. Springer-Verlag, New York, New York, USA.

Botkin, D. B., J. F. Janak, and J. R. Wallis. 1972. Some ecological consequences of a computer model of forest growth. Journal of Ecology 60:649-672.

Brookes, P. C., A. Landman, G. Pruden, and D. S. Jenkinson. 1985. Chloroform fumigation and the release of soil nitrogen: a rapid direct extraction method for measuring microbial biomass nitrogen in soil. Soil Biology and Biochemistry 17:837-842.

Brooks, P. D., J. M. Stark, B. B. McInteer, and T. Preston. 1989. A diffusion method to prepare soil $\mathrm{KCl}$ extracts for ${ }^{15} \mathrm{~N}$ analysis. Soil Science Society of America Journal 53: 1707-1711.

Cleveland, C. C., A. R. Townsend, D. S. Schimel, H. Fisher, R. W. Howarth, L. O. Hedin, S. S. Perakis, E. F. Latty, J. C. Von Fischer, A. Elseroad, and M. F. Wasson. 1999. Global patterns of terrestrial nitrogen $\left(\mathrm{N}_{2}\right)$ fixation in natural ecosystems. Global Biogeochemical Cycles 13:623-645.

Couteaux, M. M., and Z. Sallih. 1994. Fate of inorganic ${ }^{15} \mathrm{~N}$ in the profile of different coniferous forest soils. Biology and Fertility of Soils 17:101-107.

Covington, W. W. 1981. Changes in forest floor organic matter and nutrient content following clear cutting in northern hardwoods. Ecology 56:715-720.
Crow, T. R. 1978. Biomass and production in three contiguous forests in northern Wisconsin. Ecology 59:265-273.

Crow, T. R., D. S. Buckley, E. A. Nauertz, and J. C. Zasada. 2001. Effects of management on the composition and structure of northern hardwood forests in upper Michigan, USA. Forest Science, in press.

Crow, T. R., G. D. Mroz, and M. R. Gale. 1991. Regrowth and nutrient accumulations following whole-tree harvesting of a maple-oak forest. Canadian Journal of Forest Research 21:1305-1315.

Davidson, E. A., R. W. Eckert, S. C. Hart, and M. K. Firestone. 1989. Direct extraction of microbial biomass nitrogen from forest and grassland soils of California. Soil Biology and Biochemistry 21:773-778.

Davidson, E. A., S. C. Hart, and M. K. Firestone. 1992. Internal cycling of nitrate in soils of a mature coniferous forest. Ecology 73:1148-1156.

D'Elia, C. F., P. A. Steudler, and N. Corwin. 1977. Determination of total nitrogen in aqueous samples using persulfate digestion. Limnology and Oceanography 22:760764.

Eno, C. F. 1960. Nitrate production in the field by incubating the soil in polyethylene bags. Soil Science Society of America Proceedings 24:277-279.

Federer, C. A., and D. Lash. 1978. BROOK: a hydrologic simulation model for eastern forests. Water Resource Research Center Research Report 19. University of New Hampshire, Durham, New Hampshire, USA.

Fenn, M. E., M. A. Poth, J. D. Aber, J. S. Baron, B. T. Bormann, D. W. Johnson, A. D. Lemly, S. G. McNulty, D. F. Ryan, and R. Stottlemyer. 1998. Nitrogen excess in North American ecosystems: predisposing factors, ecosystem responses, and management strategies. Ecological Applications 8:706-733.

Frazer, D. W., J. G. McColl, and R. F. Powers. 1990. Soil nitrogen mineralization in a clearcutting chronosequence in a northern California conifer forest. Soil Science Society of America Journal 54:1145-1152.

Goodburn, J. M., and C. G. Lorimer. 1998. Cavity trees and coarse woody debris in old-growth and managed northern hardwood forests in Wisconsin and Michigan. Canadian Journal of Forest Research 28:427-438.

Gore, J. A., and W. A. Patterson III. 1986. Mass of downed wood in northern hardwood forests in New Hampshire: potential effects of forest management. Canadian Journal of Forest Research 16:335-339.

Gorham, E., P. M. Vitousek, and W. A. Reiners. 1979. The regulation of chemical budgets over the course of terrestrial ecosystem succession. Annual Review of Ecology and Systematics 10:53-84.

Gower, S. T., R. E. McMurtrie, and D. Murty. 1996. Aboveground net primary production decline with stand age: potential causes. Trends in Evolution and Ecology 11:378382.

Hale, C. M., J. Pastor, and K. A. Rusterholz. 1999. Comparison of structural and compositional characteristics in old-growth and mature, managed hardwood forests of Minnesota, U.S.A. Canadian Journal of Forest Research 29: 1479-1489.

Harmon, M. E., J. F. Franklin, F. J. Swanson, P. Sollins, S. V. Gregory, J. D. Lattin, N. H. Anderson, S. P. Cline, N. G. Aumen, J. R. Sedell, G. W. Lienkamper, K. Cromack Jr., and K. W. Cummins. 1986. Ecology of coarse woody debris. Advances in Ecological Research 15:133-302.

Hart, S. C., M. K. Firestone, E. A. Paul, and J. L. Smith. 1993. Flow and fate of soil nitrogen in an annual grassland and a young mixed-conifer forest. Soil Biology and Biochemistry 25:431-442.

Hart, S. C., G. E. Nason, D. D. Myrold, and D. A. Perry. 1994a. Dynamics of gross nitrogen transformations in an 
old-growth forest: the carbon connection. Ecology 75:880891.

Hart, S. C., and J. M. Stark. 1997. Nitrogen limitation of the microbial biomass in an old-growth forest soil. Ecoscience 4:91-98.

Hart, S. C., J. M. Stark, E. A. Davidson, and M. K. Firestone. 1994b. Nitrogen mineralization, immobilization, and nitrification. Pages 985-1018 in Methods of soil analysis, part 2. Microbiological and biochemical properties. Soil Science Society of America Book Series, number 5. Madison, Wisconsin, USA.

He, X. T., F. J. Stevenson, R. L. Mulvaney, and K. R. Kelley. 1988. Incorporation of newly immobilized ${ }^{15} \mathrm{~N}$ into stable organic forms in soil. Soil Biology and Biochemistry 20: $75-81$.

Hedin, L. O., J. J. Armesto, and A. H. Johnson. 1995. Patterns of nutrient loss from unpolluted, old-growth temperate forests: an evaluation of biogeochemical theory. Ecology 76: 493-509.

Hendershot, W. H., and F. Courchesne. 1991. Comparison of soil solution chemistry in zero tension and ceramic-cup tension lysimeters. Journal of Soil Science 42:577-583.

Holmes, W. E., and D. R. Zak. 1999. Soil microbial control of nitrogen loss following clear-cut harvest in northern hardwood ecosystems. Ecological Applications 9:202-215.

Host, G. E., S. Westin, W. Cole, and K. S. Pregitzer. 1989. The microcomputer software series 5: BIOMASS, an interactive program to calculate above-ground biomass of common tree species of Lake States forests. USDA Forest Service North Central Forest Experiment Station, St. Paul, Minnesota, USA.

Jenny, H., S. P. Gessel, and B. T. Bingham. 1949. Comparative study of decomposition rates of organic matter in temperate and tropical regions. Soil Science 68:419-432.

Joslin, J. D., P. A. Mays, M. H. Wolfe, J. M. Kelly, R. W. Garber, and P. F. Brewer. 1987. Chemistry of tension lysimeter water and lateral flow in spruce and hardwood stands. Journal of Environmental Quality 16:152-160.

Kirkham, D., and W. W. Bartholomew. 1954. Equations for following nutrient transformations in soil, utilizing tracer data. Soil Science Society of America Proceedings 18:3334.

Likens, G. E., C. T. Driscoll, D. C. Buso, T. C. Siccama, C. E. Johnson, G. M. Lovett, D. F. Ryan, T. J. Fahey, and W. A. Reiners. 1994. The biogeochemistry of potassium at Hubbard Brook. Biogeochemistry 25:61-125.

Litaor, M. I. 1988. Review of soil solution samplers. Water Resources Research 24:727-733.

Magill, A. H., J. D. Aber, J. J. Hendricks, R. D. Bowden, J. M. Melillo, and P. A. Stuedler. 1997. Biogeochemical response of forest ecosystems to simulated chronic nitrogen deposition. Ecological Applications 7:402-415.

Martin, C. W. 1979. Precipitation and streamwater chemistry in an undisturbed forested watershed in New Hampshire. Ecology 60:36-42.

McCarthy, B. C., and R. R. Bailey. 1994. Distribution and abundance of coarse woody debris in a managed forest landscape of the central Appalachians. Canadian Journal of Forest Research 24:1317-1329.

Merrill, A. G., and D. R. Zak. 1992. Factors controlling denitrification in upland and swamp forests. Canadian Journal of Forest Research 22:1597-1604.

Nadelhoffer, K. J., J. D. Aber, and J. M. Melillo. 1983. Leaflitter production and soil organic matter dynamics along a nitrogen-availability gradient in Southern Wisconsin (USA.) Canadian Journal of Forest Research 13:12-21.

National Atmospheric Deposition Program (NRSP-3)/National Trends Network. 1999. NADP Program Office, Illinois State Water Survey, 2204 Griffith Drive, Champaign, Illinois 61820 USA.
Pardo, L. H., C. T. Driscoll, and G. E. Likens. 1995. Patterns of nitrate loss from a chronosequence of clear-cut watersheds. Water, Air, and Soil Pollution 85:1659-1664.

Pastor, J., J. Aber, C. McClaugherty, and J. M. Melillo. 1984. Aboveground production and $\mathrm{N}$ and $\mathrm{P}$ cycling along a nitrogen mineralization gradient on Blackhawk Island, Wisconsin. Ecology 65:256-268.

Pastor, J. J., and J. G. Bockheim. 1984. Distribution and cycling of nutrients in an aspen-mixed-hardwood-spodosol ecosystem in northern Wisconsin. Ecology 65:339-353.

Perakis, S. S., and L. O. Hedin. 2001. Fluxes and fates of nitrogen in soil of an unpolluted old-growth temperate forest, southern Chile. Ecology 82:2245-2260.

Reich, P. B., D. F. Grigal, J. D. Aber, and S. T. Gower. 1997. Nitrogen mineralization and productivity in 50 hardwood and conifer stands on diverse soils. Ecology 78:335-347.

Ryan, M. G., D. Binkley, and J. H. Fownes. 1997. Agerelated decline in forest productivity: pattern and process. Advances in Ecological Research 27:213-262.

Schimel, J. P., and M. K. Firestone. 1989a. Inorganic N incorporation by coniferous forest floor material. Soil Biology and Biochemistry 21:41-46.

Schimel, J. P., and M. K. Firestone. 1989b. Nitrogen incorporation and flow through a coniferous forest soil profile. Soil Science Society of America Journal 53:779-784.

Schlesinger, W. H. 1977. Carbon balance in terrestrial detritus. Annual Review of Ecology and Systematics 8:51-81.

Seely, B., and K. Lajtha. 1997. Application of a ${ }^{15} \mathrm{~N}$ tracer to simulate and track the fate of atmospherically deposited $\mathrm{N}$ in the coastal forests of the Waquoit Bay Watershed, Cape Cod, Massachusetts. Oecologia 112:393-402.

Sheldrick, B. H., and C. Wang. 1993. Particle size distribution. Pages 499-512 in M. R. Carter, editor. Soil sampling and methods of analysis. Canadian Society of Soil Science, Lewis, Boca Raton, Florida, USA.

Sokal, R. R., and F. R. Rohlf. 1981. Biometry. The principles and practice of statistics in biological research. Second edition. W. H. Freeman, New York, New York, USA

Sollins, P. 1982. Input and decay of coarse woody debris in coniferous stands in western Oregon and Washington. Canadian Journal of Forest Research 12:18-28.

Sollins, P., C. C. Grier, F. M. McCorison, K. Cromack, R. Fogel, and R. L. Fredricksen. 1980. The internal element cycles of an old-growth Douglas-fir ecosystem in western Oregon. Ecological Monographs 50:261-285.

Stark, J. M., and S. C. Hart. 1997. High rates of nitrification and nitrate turnover in undisturbed conifer forests. Nature 385:61-64.

Tritton, L. M. 1980. Dead wood in the northern hardwood forest ecosystem. Dissertation. Yale University, New Haven, Connecticut, USA.

Tyrrell, L. E., and T. R. Crow. 1994. Structural characteristics of old-growth hemlock-hardwood forests in relation to age. Ecology 75:370-386.

Van Wagner, C. E. 1968. The line intersect method in forest fuel sampling. Forest Science 14:20-26.

Vitousek, P. M. 1977. The regulation of element concentrations in mountain streams in the northeastern United States. Ecological Monographs 47:65-87.

Vitousek, P. M., T. J. Fahey, and D. W. Johnson. 1988. Element interactions in forest ecosystems: succession, allometry, and input-output budgets. Biogeochemistry 5:7-34.

Vitousek, P. M., L. O. Hedin, P. A. Matson, J. H. Fownes, and J. Neff. 1998. Within-system element cycles, inputoutput budgets, and nutrient limitation. Pages 432-451 in M. L. Pace and P. M. Groffman, editors. Successes, limitations, and frontiers in ecosystem science. Springer-Verlag, New York, New York, USA.

Vitousek, P. M., and P. A. Matson. 1985. Disturbance, nitro- 
gen availability, and nitrogen losses in an intensively managed loblolly pine plantation. Ecology 66:1360-1376.

Vitousek, P. M., and W. A. Reiners. 1975. Ecosystem succession and nutrient retention: a hypothesis. BioScience 25:376-381.

Vitousek, P. M., K. VanCleve, and P. A. Matson. 1989. Nitrogen availability and nitrification during succession: primary, secondary and old-field seres. Plant and Soil 115:229-239. Vorosmarty, C. J., C. A Federer, and A. L Schloss. 1998. Potential evaporation functions compared on US watersheds: possible implications for global-scale water balance and terrestrial ecosystem modelling. Journal of Hydrology 207:147-169.
Whittaker, R. H., F. H. Bormann, G. E. Likens, and T. G. Siccama. 1974. The Hubbard Brook ecosystem study: forest biomass and production. Ecological Monographs 44: 233-252.

Zak, D. R., G. E. Host, and K. S. Pregitzer. 1989. Regional variability in nitrogen mineralization, nitrification, and overstory biomass in northern lower Michigan. Canadian Journal of Forest Research 19:1521-1526.

Zogg, G. P., D. R. Zak, K. S. Pregitzer, and A. J. Burton. 2000. Microbial immobilization and the retention of anthropogenic nitrate in a northern hardwood forest. Ecology 81:1858-1866. 